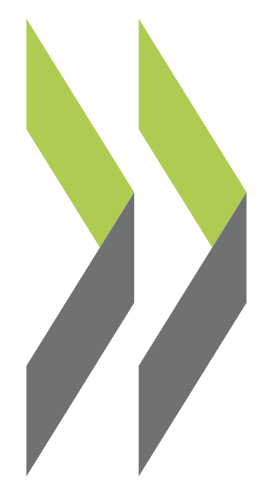

OECD Economics Department Working Papers No. 914

Addressing Challenges in the Energy Sector Philip Hemmings

in Israel 
Organisation de Coopération et de Développement Économiques

Organisation for Economic Co-operation and Development

06-Dec-2011

ECONOMICS DEPARTMENT

English - Or. English

ADDRESSING CHALLENGES IN THE ENERGY SECTOR IN ISRAEL

ECONOMICS DEPARTMENT WORKING PAPER No. 914

By Philip Hemmings

All OECD Economics Department Working Papers are available on the OECD Intranet website at www.oecd.org/eco/workingpapers

JT03312942

Document complet disponible sur OLIS dans son format d'origine

Complete document available on OLIS in its original format 


\section{ABSTRACT/RÉSUMÉ}

\section{Addressing challenges in the energy sector in Israel}

Offshore natural-gas discoveries have released Israel from complete reliance on imported primary fuels and are allowing for a cleaner energy mix. Furthermore, additional production will soon come on stream, and there is a reasonable chance of new commercially viable gas finds, and possibly of oil too. The authorities have overhauled the system of royalties and taxes, although how best to use the resulting revenues remains the subject of debate. Concerns about competition in the gas sector have risen following the disruption of imports via the pipeline from Egypt, which has strengthened the market position of the lead consortium developing the offshore fields. Competition concerns in the electricity sector have been longstanding due to sluggish reform away from monopoly provision by the state-owned incumbent. As elsewhere, energy use has important environmental side-effects. A comprehensive plan for reducing greenhouse-gas emissions has been developed recently, which relies primarily on energy-efficiency measures and an increase in the share of renewable-electricity product. This Working Paper relates to the OECD 2011 Economic Survey of Israel (www.oecd.org/eco/surveys/Israel).

JEL classification codes: L94, L95, Q41, Q42, Q48, Q53, Q54, Q58, R48

Keywords: Israel, energy, Israeli energy demand, Israeli energy supply, natural gas, electricity generation, renewable energy, greenhouse gases, GHG, solar power, wind power, energy efficiency, carbon tax, vehicle emissions, vehicle taxation, gasoline, diesel, electric car, public transport.

$* * * * * * * * * *$

\section{Relever les défis dans le secteur énergétique en Israël}

Les découvertes de gaz naturel en mer ont affranchi Israël d'une totale dépendance à l'égard des importations d'énergies primaires et elles permettent au pays de disposer d'une palette énergétique moins polluante. De plus, de nouvelles capacités de production vont bientôt devenir opérationnelles et il y a des perspectives raisonnables de nouvelles découvertes de gaz commercialement viables, et peut-être aussi de pétrole. Les autorités ont revu le système des royalties et taxes, même si la façon d'utiliser au mieux les recettes recueillies reste sujet à débat. Les préoccupations liées à la concurrence dans le secteur gazier se sont accentuées après les perturbations des importations transitant par le gazoduc avec l'Égypte, qui ont renforcé la position sur le marché du consortium pilote développant les gisements offshore. Le problème de concurrence dans le secteur de l'électricité dure depuis longtemps en raison de la lenteur de la réforme en faveur de l'abandon de la position monopolistique de l'opérateur appartenant à l'État. Comme ailleurs, la consommation d'énergie a d'importants effets secondaires sur l'environnement. Un plan d'ensemble de réduction des émissions de gaz à effet de serre a été élaboré récemment, qui s'appuie principalement sur des mesures d'efficacité énergétique et l'augmentation de la part d'électricité produite à partir d'énergies renouvelables. Ce Document de travail se rapporte à l'Étude économique de l'OCDE d'Israël 2011 (www.oecd.org/eco/etudes/Israël).

Classification JEL: L94, L95, Q41, Q42, Q48, Q53, Q54, Q58, R48

Mots-clés: Israël, énergie, demande énergétique israélienne, offre énergétique israélienne, gaz naturel, production d'électricité, énergie renouvelable, gaz à effet de serre, GES, installations solaires, éoliennes, efficacité énergétique, taxe carbone, émissions des véhicules, fiscalité des véhicules, essence, diesel, voiture électrique, transport public.

Copyright $\odot$ OECD, 2011 Application for permission to reproduce or translate all, or part of, this material should be made to: Head of Publications Service, OECD, 2 rue André Pascal, 75775 Paris Cedex 16, France. 


\section{Table of contents}

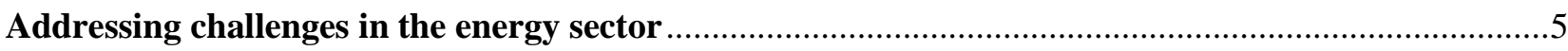

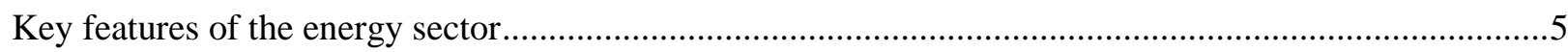

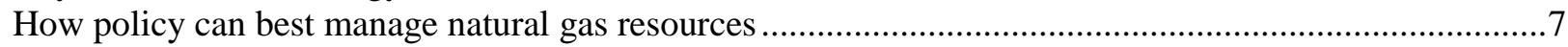

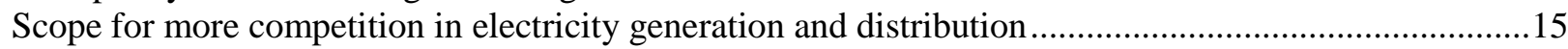

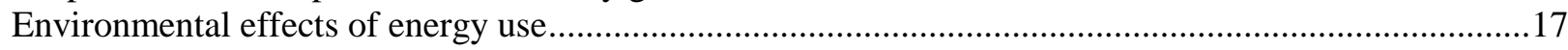

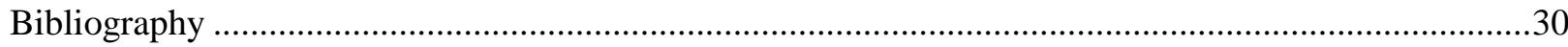

\section{Boxes}

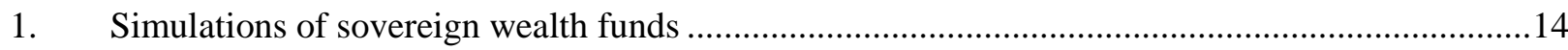

2. The main features of electricity tariff setting by the PUA ….....................................................16

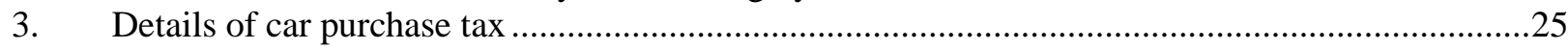

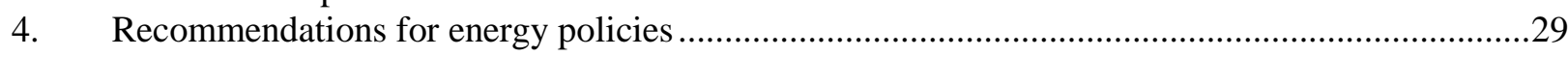

\section{Tables}

1. Key bodies responsible for energy (and related) policies ..........................................................

2. Summary of natural gas resources and supplies (as of October 2011) .........................................

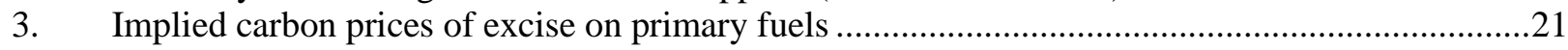

4. Progress in plans to increase solar- and wind-powered electricity generation...............................22

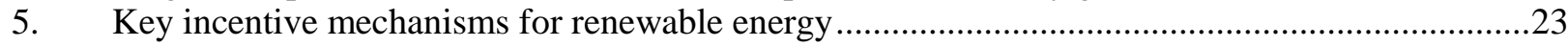

\section{Figures}

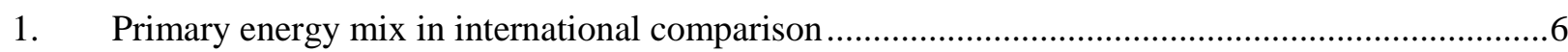

2. Energy intensity and $\mathrm{CO}_{2}$ emissions in international comparison ...........................................

3. Natural gas reserves in international comparison ..............................................................10

4. A possible production and demand scenario for Israel's natural gas ............................................11

5. Comparison of the government take under the new tax-royalty regime .....................................13

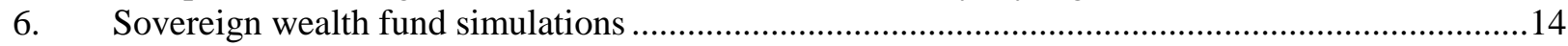

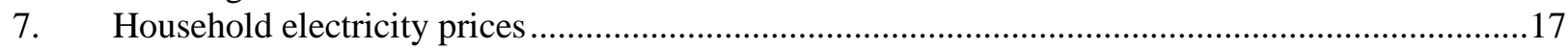

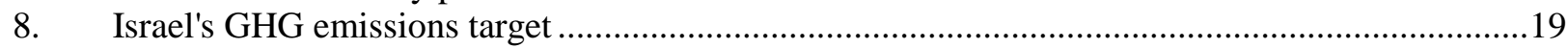

9. International comparison of the change in emissions implied by GHG targets ............................19

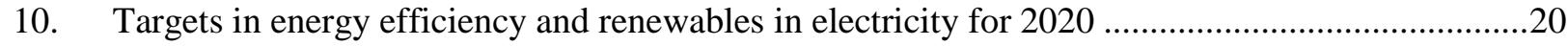

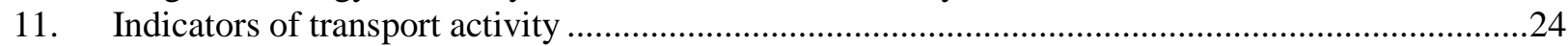

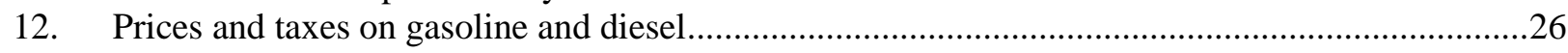

13. Taxes on gasoline and diesel compared with estimates of externalities .....................................27

This document and any map included herein are without prejudice to the status of or sovereignty over any territory, to the delimitation of international frontiers and boundaries and to the name of any territory, city or area.

The statistical data for Israel are supplied by and under the responsibility of the relevant Israeli authorities. The use of such data by the OECD is without prejudice to the status of the Golan Heights, East Jerusalem and Israeli settlements in the West Bank under the terms of international law. 
ECO/WKP(2011)83 
ECO/WKP(2011)83

\title{
Addressing challenges in the energy sector in Israel
}

\author{
By Philip Hemmings ${ }^{1}$
}

Recent discoveries of offshore natural gas are reducing Israel's heavy reliance on coal and oil. Coupled with the possibility of further finds, they have also raised the prospect of sizeable tax and royalty revenues in the future. However, the extent of competition in the gas sector is a source of concern, and the supply chain for electricity remains almost entirely run by a vertically-integrated state-owned dominant incumbent. Furthermore, Israel has made a late start on commitments to reduce greenhouse-gas emissions. This paper focuses on how best policy can address these opportunities and challenges.

The distribution of responsibilities for Israeli policies related to the energy sector is fairly typical. On paper at least, the Ministry of National Infrastructures has important responsibilities in the formulation of policies relating to the energy sector (Table 1). The Ministry of Environmental Protection has gained greater prominence in determining energy-related policies, and other ministries, such as the Ministry of Transport, obviously play a role in shaping energy use. However, as with many other policy areas, the Ministry of Finance often plays a leading role in setting the policy agenda and in detailing specific measures.

\section{Key features of the energy sector}

Israel's energy sector is atypical in several respects:

- Offshore natural gas is significantly reducing dependence on imported oil and coal. Until the mid-2000s, primary energy supply was almost entirely met via shipped imports of crude oil (or derived products) and coal (Figure 1). Domestic offshore natural gas began to come on stream in 2004. Production and estimates of future reserves have been increasing since then. In addition, a pipeline importing natural gas from Egypt became operational in 2008, but supplies have been interrupted several times in 2011. Natural gas accounted for $20 \%$ of primary energy supplies in 2010. Even so, Israel still remains relatively dependent on oil and coal compared with most OECD countries.

1. Head of the Israel Desk in the OECD Economics Department. This paper was produced for the OECD Economic Survey of Israel (http://www.oecd.org/eco/surveys/israel) published in December 2011 under the authority of the Economic and Development Review Committee. The author is particularly indebted to OECD staff members Andrew Dean, Bob Ford and Peter Jarrett (Economics Department), Brendan Gillespie, Ivana Capozza and Nils-Axel Braathen (Environment Directorate), and Christopher Segar and his team (International Energy Agency) for their valuable comments and to Françoise Correia for research assistance and to Mee-Lan Frank for editorial support. The paper has also benefitted enormously from discussions with policymakers and experts the Ministry of National Infrastructures, Ministry of Environmental Protection, Ministry of Finance and the Bank of Israel. 
Table 1. Key bodies responsible for energy (and related) policies

\begin{tabular}{ll}
\hline \multicolumn{1}{c}{ Body } & \multicolumn{1}{c}{ Role } \\
\hline $\begin{array}{l}\text { Ministry of National } \\
\text { Infrastructures }\end{array}$ & $\begin{array}{l}\text { Overall responsibility for electricity, gas and oil-based fuel sectors, as well as water } \\
\text { resources. All supervision of the gas sector operates from within the Ministry. For the } \\
\text { electricity sector, the Ministry covers all dimensions not covered by the PUA (see } \\
\text { below), notably the approval of investment programmes for generation, transmission } \\
\text { and distribution. The various state-owned companies (notably the Israel Electricity } \\
\text { Corporation) also fall under the Ministry's responsibility. }\end{array}$ \\
\hline $\begin{array}{l}\text { Public Utilities } \\
\text { Authority-Electricity (PUA) }\end{array}$ & $\begin{array}{l}\text { Established by the 1996 Israeli Electricity Market Law, independent by law and } \\
\text { separate from the Ministry of National Infrastructures in terms of budget and staff. } \\
\text { Responsible for setting electricity tariffs and standards for the quality of service; and, } \\
\text { as of 2005, also responsible for the issuing of licences to electricity-market } \\
\text { participants (notably the independent power producers or IPPs). The PUA also } \\
\text { advises the Ministry of National Infrastructures on investment projects. }\end{array}$ \\
\hline Natural Gas Authority & $\begin{array}{l}\text { Supervisor of the gas sector, established in 2003 and independent but also operating } \\
\text { "within" the Ministry of National Infrastructures. }\end{array}$ \\
\hline Ministry of Environmental & $\begin{array}{l}\text { Plays a key role in getting environmental issues on the policy agenda for energy and } \\
\text { climate change. }\end{array}$ \\
\hline Protection & $\begin{array}{l}\text { Typically plays a central role in strategic decisions and in the design of specific } \\
\text { programmes. }\end{array}$ \\
\hline
\end{tabular}

Figure 1. Primary energy mix in international comparison

Total primary energy supply in 2010 , percentage of total ${ }^{1}$

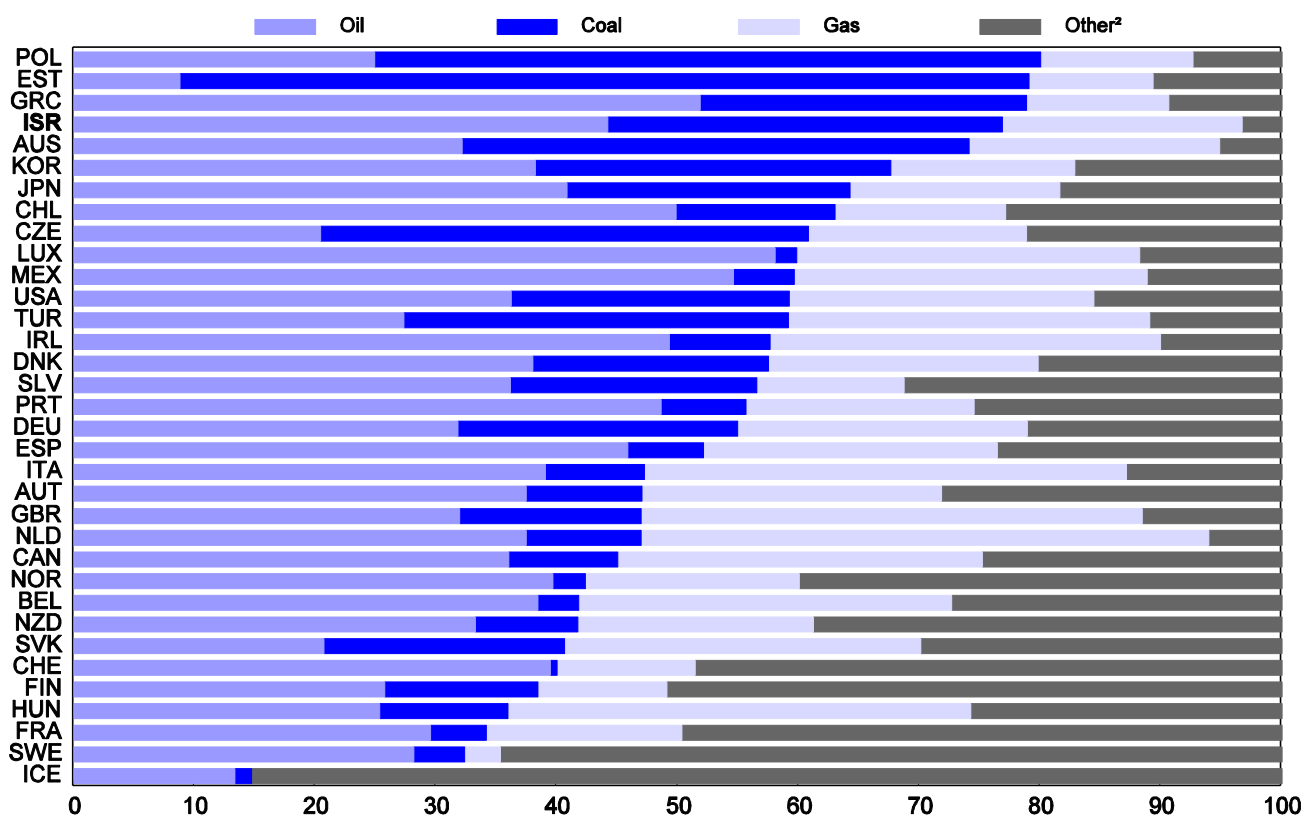

1. Data sorted by the combined share of oil and coal in the energy mix.

2. Other includes nuclear, hydro, solar, wind, tide/wave/ocean energy, combustible renewables and waste.

Source: International Energy Agency, World Energy Balances database and OECD calculations. 
- In other respects the energy economy remains extremely self-sufficient. Electricity is entirely generated domestically, and there are no grid connections with any neighbouring economies, aside from Gaza and the West Bank, where Israel has commitments to supply energy. Similarly, there is no substantial land-based cross-border trade in crude oil or refined products. Israel's geopolitical situation is probably the key factor in this paucity of (land-based) energy connections. Geopolitics also mean energy security is a prominent issue. The pipeline disruptions have served as a reminder of Israel's vulnerability on this front and underscore the particular importance of maintaining multiple sources of supply.

- Energy intensity, both on a per capita basis and relative to GDP, is fairly low in international comparison (Figure 2) Contributing factors are relatively small energy-intensive sectors, a reasonably favourable climate, high population density and middle-ranking GDP per capita (in the OECD context). However, total energy demand will continue to grow faster than in most other OECD countries due to high population and per capita GDP growth.

- However, the energy sector ranks less favourably in terms of $\mathrm{CO}_{2}$ eq emissions (Figure 2). The comparatively low energy intensity is compromised by a relatively high production of $\mathrm{CO}_{2}$ eq per unit of energy produced due to the high share of coal and oil in the primary energy mix. This share will be reduced in the future but is unlikely to attain the low levels reached by a number of other countries, largely because a significant share of coal-fired electricity generation is likely to be retained for reasons of energy security and price uncertainty.

- Renewable energy via solar-thermal panels for water heating has long been extensively exploited. Therefore, conceptually, some electricity consumption (or other type of heating fuel consumption) has already been replaced by a renewable source. Electricity generation from renewable sources has so far been limited in scope, but there is potential for more. Not only are climatic conditions suitable for solar power but Israeli firms and institutions are also involved in technological developments in this area, thus presenting the possibility of advantageous green-growth synergies. ${ }^{2}$

\section{How policy can best manage natural gas resources}

\section{Development of reserves to date}

Since 2004, production and estimated reserves of natural gas have increased significantly. Most of the initial production has been from the Mari-B deposit, which is part of the Yam Tethys field (see Table 2 and Shaffer, 2011). The development of this field ran roughly parallel to the construction of a land-based pipeline for importing natural gas from Egypt. These twin developments are commonly cited as helping the authorities negotiate favourable prices and supply conditions. Within the next few years, the Yam Tethys reserves will be exhausted (indeed, in 2011 they have been depleted more rapidly than previously expected due to the shortfalls from stoppages in supplies from Egypt). However, other deposits are due to come on stream, most notably from the much larger Tamar field and later the even larger Leviathan field. In total

2. For example the first solar generating systems built in the 1980s in California were based on technologies developed by an Israeli company. Also, the Weizmann Institute has a long track record in solar-energy research. See International Energy Agency (2010a and 2010b) for an overview of sectoral developments. 
Figure 2. Energy intensity and $\mathrm{CO}_{2}$ emissions in international comparison

A. TPES' per capita
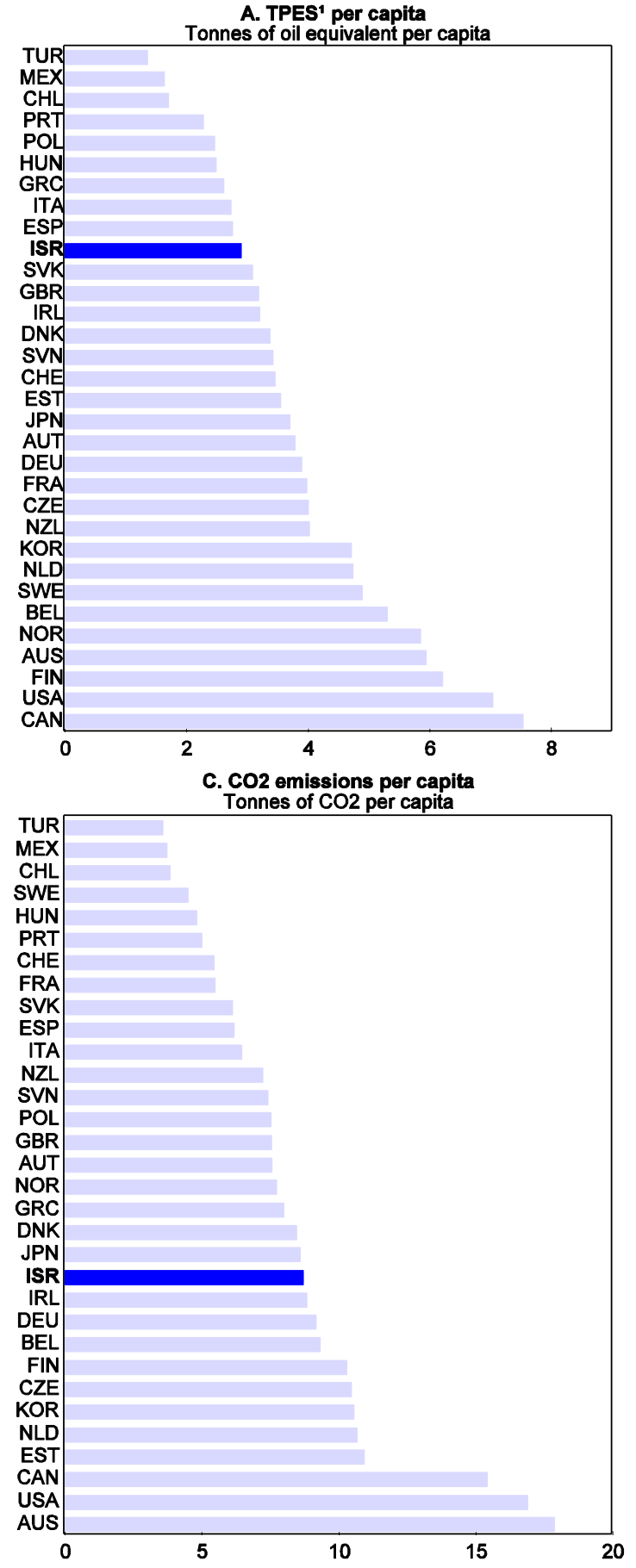

B. TPES' per GDP

Tonnes per thousand 2000 USD PPP

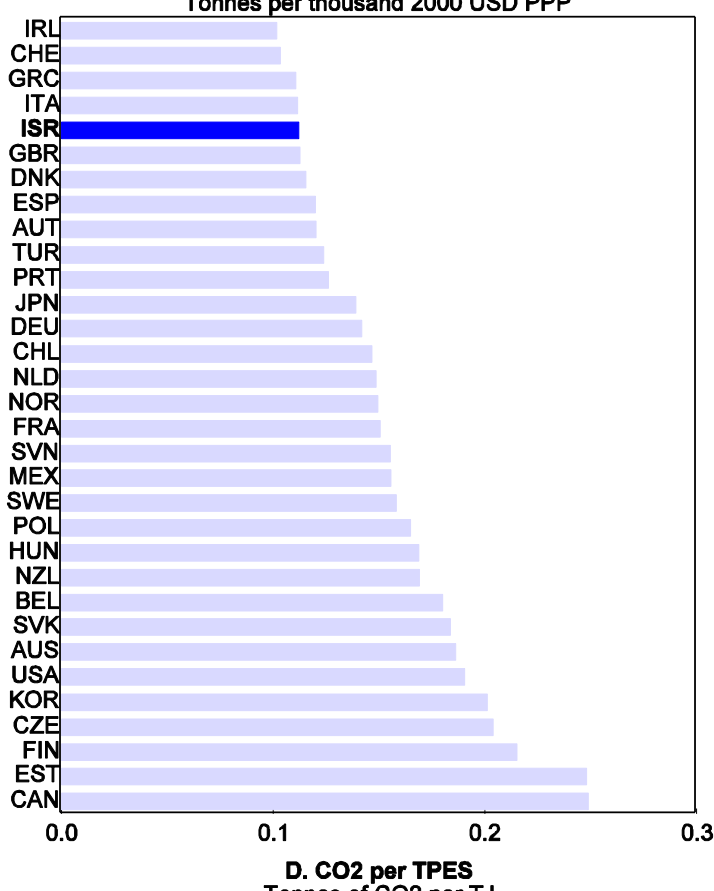

Tonnes of $\mathrm{CO} 2$ per $\mathrm{TJ}$

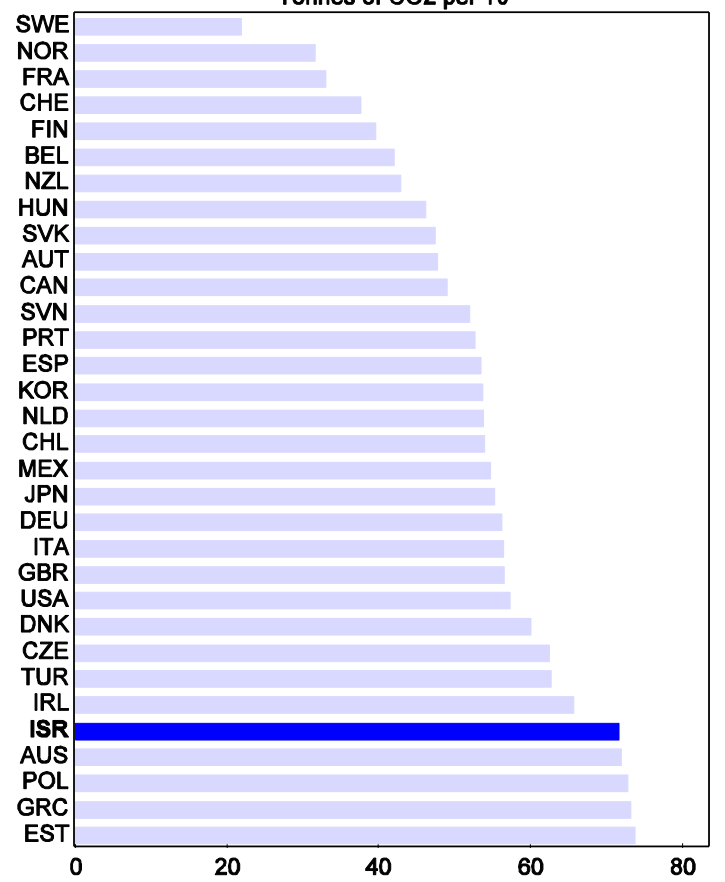

1. Total primary energy supply.

Source: OECD, OECD.stat - Energy database. 
ECO/WKP(2011)83

Table 2. Summary of natural gas resources and supplies (as of November 2011)

\begin{tabular}{|c|c|}
\hline Field & Development to date \\
\hline \multicolumn{2}{|l|}{ Offshore fields } \\
\hline Yam Tethys & $\begin{array}{l}\text { Most production has been from the "Mari-B" deposit which has been supplying gas to the } \\
\text { Israel Electricity Corporation (IEC) since } 2004 \text {. As of } 2010 \text {, approximately } 17 \text { bcm had } \\
\text { been extracted and } 10-15 \text { bcm remained. The deposit is projected to be fully exhausted } \\
\text { within the next few years. }\end{array}$ \\
\hline Tamar & $\begin{array}{l}\text { Test drilling in } 2008 \text { confirmed reserves of around } 250 \mathrm{bcm} \text { (184 bcm are classified as } \\
\text { "proven" and the remainder as "proven and probable"). Reports suggest production will } \\
\text { probably commence in } 2013 \text {. }\end{array}$ \\
\hline Leviathan & $\begin{array}{l}\text { Exploratory drilling at the end of } 2010 \text { indicated approximately } 450 \mathrm{bcm} \text { of producible } \\
\text { gas, although this has yet to be confirmed as a "proven" reserve. According to press } \\
\text { reports, production could commence as early as } 2016 \text {. }\end{array}$ \\
\hline Myra and Sarah & $\begin{array}{l}\text { A geological survey in June } 2011 \text { indicated a best estimate of reserves of } 180 \mathrm{bcm} \text {, but } \\
\text { there is a wide range between lower and upper estimates. }\end{array}$ \\
\hline $\begin{array}{l}\text { Other possible gas } \\
\text { reserves }\end{array}$ & $\begin{array}{l}\text { An analysis by the US Geological Survey (Schenk et al., 2010) estimated total } \\
\text { recoverable resources in the Levant Basin of the eastern Mediterranean of } \\
\text { approximately } 3400 \text { bcm of which approximately two-thirds lies within Israeli waters. } \\
\text { Taking into account current reserves, this implies perhaps an additional } 1500 \text { bcm or } \\
\text { more in total recoverable resources. }\end{array}$ \\
\hline \multicolumn{2}{|l|}{ Other sources } \\
\hline Egyptian pipeline & $\begin{array}{l}\text { Operational since February } 2008 \text {, with supply under contracts with East Mediterranean } \\
\text { Gas (EMG). Prior to recent disruptions the pipeline provided } 2.1 \mathrm{bcm} \text { per year to the IEC } \\
\text { and approximately } 2 \text { bcm to private-sector electricity generators and industry (the } \\
\text { maximum operational capacity of the pipeline is } 7 \mathrm{bcm} \text { per year). }\end{array}$ \\
\hline Other (prospective) & $\begin{array}{l}\text { A receiving terminal for importing } L N G \text { is being planned with annual capacity of } 1 \mathrm{bcm} \text {. } \\
\text { The current proposal is for location of the offshore facility close to Hadera. }\end{array}$ \\
\hline
\end{tabular}

there are around 700 billion cubic metres (bcm) of reserves in these, although only Tamar $(250 \mathrm{bcm})$ has thus far been confirmed as proven or probable according to standard criteria. ${ }^{3}$ Most recently, there have been discoveries in the Myra and Sarah fields, although their size remains highly uncertain (estimates have not been included in calculations for this paper).

While these reserves are significant, they will not transform Israel into a resource-rich economy with powers to influence global prices on the scale seen in some countries. Even taking the total of both proven and unproven reserves (notably the Leviathan field), in global terms, the resources are very small, representing about $0.4 \%$ of the estimated world total, which is somewhere between the remaining reserves

3. A commonly used classification of reserves is as follows:

- "proven reserves" (1P reserve): those that have been discovered and for which there is a $90 \%$ probability that it can be extracted profitably on the basis of prevailing assumptions about cost, geology, technology, marketability and future prices;

- "proven and probable" (2P reserve) reserves which includes additional volumes that are thought to exist in accumulations that have been discovered and have a 50\% probability that they can be produced profitably;

- "reserves growth" typical increases in 2P reserves that occur as oil or gas fields that have already been discovered are developed and produced;

- "ultimately recoverable resources" which are the latest estimates of the total volume of hydrocarbons that are judged likely to be ultimately producible commercially, including $1 \mathrm{P}$ reserves, reserves growth and as yet undiscovered resources. 
in the United Kingdom and the Netherlands (Figure 3). On a per capita basis, the reserves are worth around USD 15 000, which is the same order of magnitude as the Netherlands, but well below that of Norway.

Figure 3. Natural gas reserves in international comparison

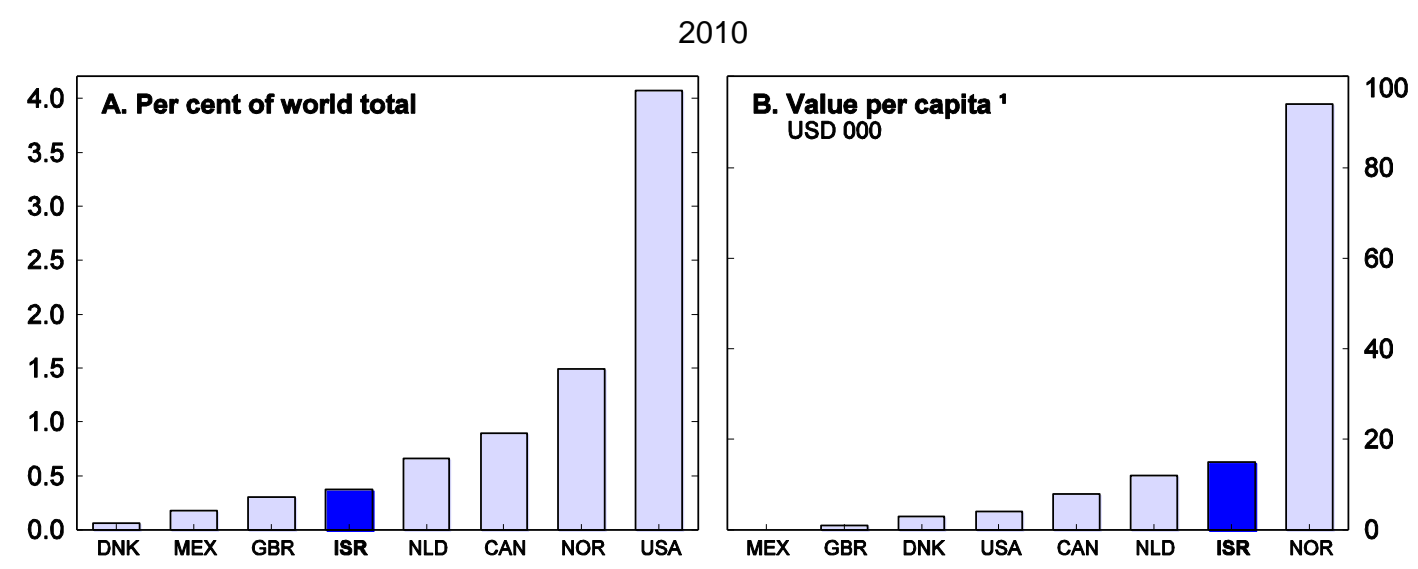

1. Assuming a gas price of USD 4.5 per million British thermal units (MMBTU), which is equivalent to USD 0.16 per cubic metre. A figure of $700 \mathrm{bcm}$ is assumed for Israel. This includes unproven reserves (the Cedigaz figure is $90 \mathrm{bcm}$ ).

Source: Cedigaz, Natural Gas in the World, 2010 Edition and OECD calculations.

Production will continue to increase and is likely to outstrip levels of domestic demand within the next few years. Domestic demand is expected to roughly match production from the Tamar field plus imports from Egypt (assuming stoppages end) for the next while through further increases in the share of natural gas in electricity production. Currently, natural gas is used in nearly $40 \%$ of electricity generation and the share is due to rise to $60 \%$ in the next 5 years given the generation profile of facilities currently under construction. While some argue the share of natural gas could be allowed to reach $70 \%$, much depends on issues in energy security and input flexibility. The demand-supply relationship is illustrated in the scenario shown in Figure 4. It underscores that, unless large-scale additional domestic demand manifests itself, production from the Leviathan field will probably be available for export. Clearly, if new discoveries are made (such as that shown by way of example in Figure 4), the possibility of export increases further. A government-appointed committee has been set up to examine the question and report early in 2012.

It is fairly likely that more gas will be found, and oil finds are also possible, but the scale of discoveries is highly uncertain. But even if the figure of some $1500 \mathrm{bcm}$ cited in Table 2 is valid, the proportion that will be successfully located and then proven to be commercially viable is difficult to gauge. Geologically, the presence of natural gas often means that there are oil resources too, adding further to the scale of possible additional resource finds. Exploratory drilling for oil is underway (for example in the Leviathan field), but, at the time of writing, there had been no significant discoveries. In addition, there has been renewed interest in Israel's onshore shale deposits, with some speculating that, with new technologies, commercially viable oil extraction is possible.

With the prospect of further growth in the role of natural gas, the authorities are planning additional external supply to that provided by the Egyptian pipeline. There are reasonably well advanced plans for a receiving terminal for liquefied natural gas (LNG), the motivation for which is primarily to cover likely shortages of natural gas in 2012 and 2013. Significant investment is also being made in upgrading the main gas transmission network, mainly via the state-owned network company Natgaz. 
Figure 4. A possible production and demand scenario for Israel's natural gas'

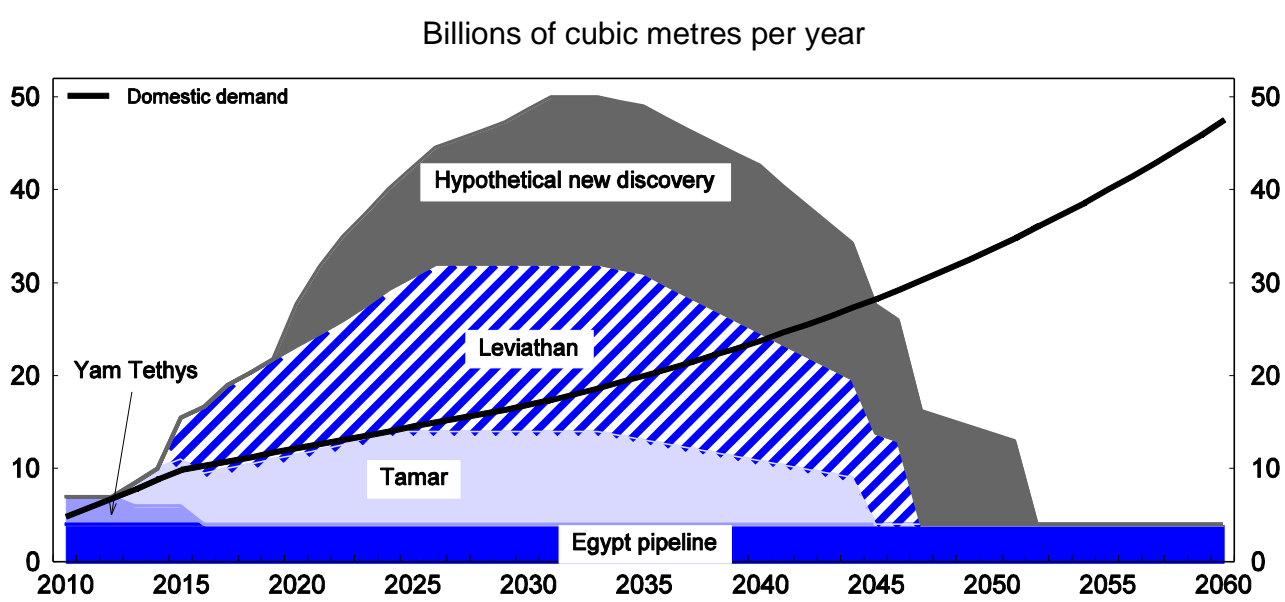

1. The production and demand trajectories represent only one of a wide range of possible scenarios. Imports from the Egypt pipeline are assumed constant at $4 \mathrm{bcm}$ per year. Yam Tethys field production assumes $15 \mathrm{bcm}$ remaining and exhaustion by 2015. The Tamar field is assumed to contain a total reserve of $250 \mathrm{bcm}$ and Leviathan $450 \mathrm{bcm}$. The production profiles are based on various sources of information. Tamar production is assumed to start in 2013, Leviathan in 2015 and the hypothetical field in 2020. Demand up to 2030 is based on a description of possible demand growth in the Sheshinski report (State of Israel, 2011) p. 17). Beyond 2030 demand is assumed to grow at $3.5 \%$.

Source: OECD.

\section{Institutional and legal framework}

The legal and institutional structure of the natural gas sector is basically sound. The Natural Gas Sector Law of 2002 included a licensing system aimed at encouraging competition in transmission and distribution and the establishment of a regulatory body (the Natural Gas Authority). In keeping with similar systems elsewhere, state ownership is confined to the network operator (Israel Natural Gas Line Ltd., established in 2004). In addition, the fiscal regime for the exploration and production of oil and natural gas has been significantly revised (see below).

However, the institutional framework would be improved if the Natural Gas Authority were fully separated from the Ministry of National Infrastructures. True, the Authority's responsibilities are fairly typical. In particular, it supervises licence holders, approves tariffs and is responsible for setting up arrangements for connection fees and their level (note, offshore exploration and development is under a separate regulator). It also certainly has many features of an independent energy regulator. For instance, it is provided with a specific budget and is managed by a director and a council comprising two state employees (including the director) and two public representatives. However, the Authority is legally defined as being "within" the Ministry of National Infrastructures, and it certainly physically operates as such. Also, the Minister of National Infrastructures recommends the appointment of the Director to the government (in consultation with the Minister of Finance) and the Director can be removed on the recommendation of the Minister. This suggests that there is risk that its independence will be compromised. In any case, policy making is conceptually different from regulation and supervision and thus should logically be separate.

Ensuring competition in the supply chain for natural gas may prove difficult. Although a large number of firms are involved in the exploration and development of the offshore gas, many are operating under a single consortium (headed by Noble Energy Inc.). Hence the roughly parallel development of the natural gas pipeline from Egypt and the offshore fields has provided useful bargaining power for the authorities, though future prospects for this have become uncertain in light of the pipeline stoppages. More competing 
players in the offshore sector would also be beneficial, though whether this is feasible partly depends on the nature of economies of scale in the industry and on the scale of discoveries in the future. The Israeli Antitrust Authority is paying welcome attention to the companies currently involved in the gas sector. For instance, in September 2011 it announced it was considering officially classifying various companies and partnerships as monopolies or cartels in gas exploration and supply.

\section{The new tax/royalty regime}

In light of the offshore gas finds, the royalty-tax regime for companies engaged in the exploration and commercial development of natural gas and oil resources has been significantly altered. The new system is based on the recommendations of an expert committee (the Sheshinski Committee; see State of Israel, 2011), which was established in April 2010 and delivered its final conclusions in January 2011. The legislation was passed by the Knesset in April 2011 with only minor concessions made with respect to the original proposal.

The new fiscal regime is markedly different from its predecessor, which had essentially remained unchanged since its establishment in the early 1950s. Importantly, it is being applied to existing as well as future operations, which was the subject of considerable debate during the finalisation of the legislation. Key aspects of the reform comprise:

- Maintaining the existing rate of royalties (12.5\% at the wellhead).

- Cancellation of a "depletion allowance" that had allowed significant reduction in taxable income. The Sheshinski Committee argued, correctly, that the allowance had no economic justification because (unlike 'regular' businesses) the oil and gas companies do not actually own the asset (i.e. the resources in the geological deposit); rather the state does.

- Introduction of "accelerated depreciation mechanisms" to accumulated costs (separate mechanisms apply to the exploration and production phases). ${ }^{4}$

- Introduction of a special annual profits levy (in addition to regular corporate profits tax) on revenues from production (net of operating expenses and royalties). The levy rate depends on the ratio of cumulative revenues to investment outlays ("R-factor"). Specifically, the numerator comprises the cumulative value of income from production net of operating expenses, royalties and previous levy payments. The denominator comprises exploration costs up to the development phase plus cumulative expenses during the development phase (including interest). The levy is imposed only once the R-factor reaches a certain level and increases progressively from $20 \%$ to a maximum of 50\%. The levy is calculated separately for each field licence (i.e. it is ring-fenced).

- Transitional provisions to lighten the fiscal burden for existing and upcoming production (i.e. the Yam Tethys and Tamar fields). For example, the minimum R-factor for imposition of the profits levy is higher for production commencing before January 2014.

4. The various stages are defined by the licensing system in the 1952 Oil Law and comprise two exploration phases and a production phase: $i$ ) a "Preliminary Permit" stage, which provides rights for preliminary exploration for up to 18 months; ii) a "Licence" stage, which provides exclusive rights to conduct seismic surveys and test drillings for up to three years (with possible annual extension up to a further three years); iii) and a "Lease" stage, which provides the exclusive rights to explore and produce. The leases are initially granted for 30 years (with possible extension for an additional 20 years). Importantly, the leaseholder is obligated to commence commercial production within three years. 
In broad terms, the new fiscal regime has raised the effective tax on resources significantly. Simulations by the Sheshinski Committee show that the ratio of fiscal to total revenues over the lifespan of extraction (the 'government take') would have been less than $30 \%$ for sizeable deposits under the previous fiscal regime (Figure 5). Under the new regime the government take has roughly doubled. For instance, according to those simulations, the take is now around $60 \%$ for a deposit of $250 \mathrm{bcm}$. This is similar to levels elsewhere. For instance, the average take among OECD countries with appreciable oil and gas exploration has been estimated to be in the range of 61-65\% (State of Israel, 2011).

Figure 5. Comparison of the government take under the new tax-royalty regime

As calculated by the Sheshinski Committee, percentage
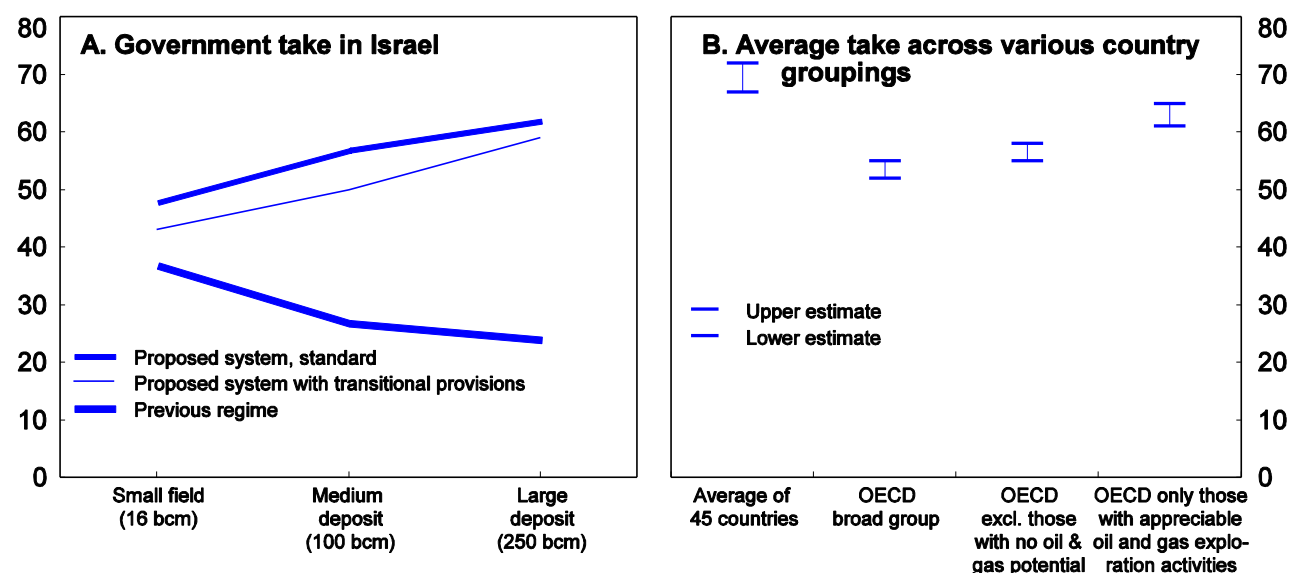

Source: Sheshinski Committee Final Report (State of Israel, 2011).

\section{Gas-related fiscal revenues should be ring-fenced}

Revenues from natural resources can all too easily be frittered away with little permanent benefit to society if directly channelled into general government revenues. In any case, on the grounds of inter-generational equity, there should be a permanent, or at least long-term, social benefit from the revenues. This is because (excluding regular corporation tax) the taxes and royalties are conceptually the proceeds from the sale of a non-renewable publicly owned resource. As such, the benefits should accrue to both current and future generations.

Bearing in mind the scale of current reserves and the reasonable prospect of further finds, a transparent commitment on how the funds will be used is needed. Revenues should neither be channelled into general government revenues, nor put into a special fund or budget line earmarked for certain areas of public spending. Probably the best way of ensuring that both current and future generations can benefit is to create an independently managed sovereign wealth fund (SWF), the purpose of which is to hold revenues from resources, allowing only a relatively small amount to be drawn off each year (typically in line with the real return on the fund, i.e. perhaps 4-5\%) for use in government spending (such as education, poverty reduction or transport infrastructure). Given the broad production pattern depicted in Figure 4, then income from natural gas could be characterised as temporary (as in Norway). Resource-related revenues will put upward pressure on the real exchange rate. This "Dutch disease" can crowd out other economic activity and significantly reduce employment, which may be difficult to re-establish once the resource is exhausted. A SWF invested abroad, as in Norway, can contain Dutch-disease effects. Also, swings in the global gas price can have undesirable consequences if the budget is not insulated by putting the proceeds into the SWF (as Chile does with its stabilisation fund). Figure 6 (see also Box 1) illustrates scenarios for a fund in which only the real return is spent each year. If the price of natural gas is assumed to remain 
constant in real terms at current levels then SWF assets would peak at less than 15\% of GDP (Figure 6, Panel C). However, more discoveries or a steady rise in the price of gas would result in significantly larger asset accumulation. The legislative and administrative framework for the SWF should be established sooner rather than later. Once revenues grow, it may prove politically impossible to then channel them into a fund because too many political commitments for using the revenue directly for public spending may have been made by that point.

\section{Box 1. Simulations of sovereign wealth funds}

Sovereign wealth funds (SWFs) can ensure a permanent (or at least a long-term) stream of income from the exploitation of a natural resource by creaming off only a small share of the fund each year (the drawdown). The simulations shown in Figure 3.6 use the production scenarios shown in Figure 3.4 to calculate government revenues and the accumulation of a hypothetical fund under various assumptions. Notably, the 'government take' is assumed to be $40 \%$, and the real rate of return on the SWF is assumed to be $5 \%$. The drawdown rate is set equal to the real rate of return.

Setting the drawdown rate equal to the real rate of return means the fund stabilises at a constant value in real terms in perpetuity. This is illustrated in the top left hand panel of Figure 3.6, which shows the accumulation of the real value of the fund over time under different scenarios. Conceptually this is attractive because it implies an income stream of constant value in real terms for all future generations. However, real GDP growth means that the size of the fund and the drawdown, as percentages of current GDP, do not stabilise at a fixed value but rather decline in the long run. This explains why the bottom panels in Figure 3.6 peak and then decline.

Figure 6. Sovereign wealth fund simulations ${ }^{1}$
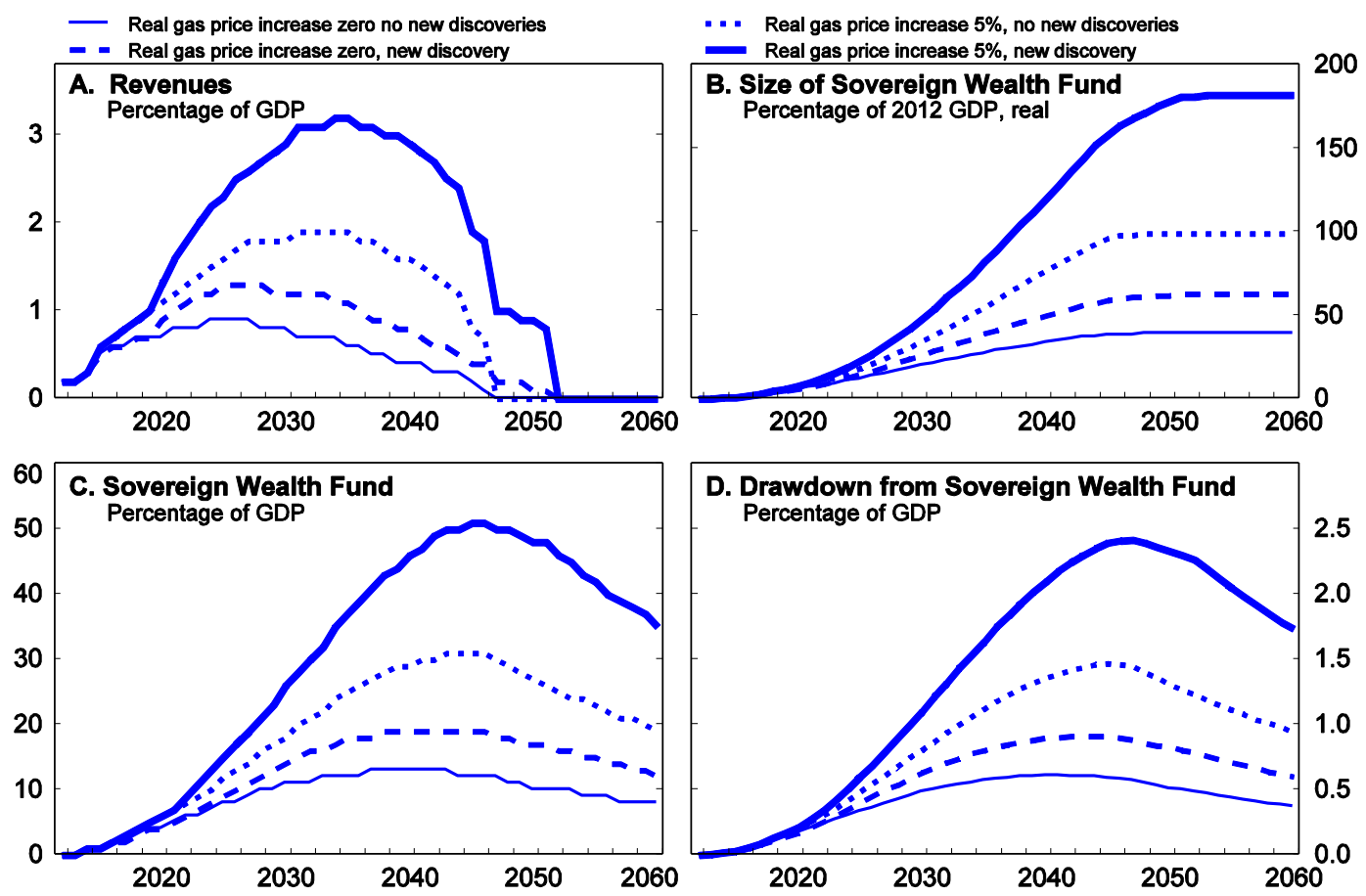

1. Production is based on the scenarios shown in Figure 3.4. Other key assumptions: 1) natural gas price of USD 6 per million British Thermal Units; 2) exchange rate NIS 3.6 per USD; 3) annual growth in prices growth and GDP deflator, 2\%; 4) real GDP growth, 3.5\%: 5) nominal interest on sovereign wealth fund, 7\%; 6) GDP in initial periods (2012) NIS 900 billion; 7) government revenues as a share of turnover ("government take"), 0.6.

Source: OECD calculations. 


\section{Demand issues}

The pace of exploration and development of natural gas partly depends on whether production can be absorbed by domestic demand and, if not, what options are technologically and economically feasible for exporting it. This can be a particularly tricky issue for natural gas resources, because, unlike coal and oil they require extensive investment for storage and transportation. The issue of an 'excess' of supply over foreseeable demand remains as yet unresolved (though a government-appointed committee has been established). As discussed earlier, it is generally believed that under a business-as-usual scenario, domestic demand can absorb up to around $10 \mathrm{bcm}$ of offshore production per year. Production from the Leviathan field implies total output well in excess of this figure, and this is likely to be augmented by new discoveries further down the line. However, as yet there is no obvious source of new domestic demand. In this regard the private sector will surely propose various gas-consuming investment projects, or export facilities, and put policymakers under pressure to contribute. Such projects may prove viable and desirable, but they should be judged ultimately mainly on commercial grounds. While the government should provide a stable and efficient regulatory and policy environment, it should resist the temptation to subsidise them. Likewise, there is little case for public subsidies to extend the domestic gas pipeline network, for instance so as to provide gas for domestic heating. This is because the public-good aspect of the network is already catered for by the electricity sector where network capacity is already installed (electricity and gas are perfect substitutes in this context).

\section{Scope for more competition in electricity generation and distribution}

Many OECD countries have opened up electricity generation and distribution to the private sector, and quite a number have brought choice of providers to the household level. Reforms in Israel have been very slow; in generation, some independent power producers (IPPs), both conventional and renewable, are due to come on stream soon, but the Israel Electric Corporation (IEC) will continue to dominate. In all other segments of the supply chain the IEC remains the sole provider.

A potentially significant step towards private-sector participation and competition was made with the passage of the Electricity Sector Law in 1996, but subsequent reform has been slow. The Law set up a framework for licensed private-sector participation throughout the electricity supply chain. ${ }^{5}$ In addition, it established an independent regulatory body, the Public Utilities Authority-Electricity (PUA). The PUA has three responsibilities: $i$ ) setting tariffs (and the method of updating them); ii) setting the criteria for the standard, nature and quality of services; and, iii) granting of licences and supervision of compliance. Without doubt the legislation was intended to pave the way for a multiple-provider system, similar to those adopted in many other OECD countries. However, the reform process subsequently lost momentum, and the costs implicit in delayed progress have been accumulating. The PUA became operational immediately, but progress in licensing private-sector participation in the supply chain has been limited. Indeed, the only advance has been in granting production licences, and this has been halting. Detailed regulations on the design of IPP contracts for the sale of electricity were not established until 2004, and the first licence was awarded only in 2009.

Although, officially, the ultimate strategic goal remains a market-based structure, concrete reform ambitions appear limited to further expansion of private generation capacity. Reasonably firm backing is being given to additional IPPs, suggesting a desire to at least reduce the IEC's market share in generation. As of November 2011 construction of IPP generation facilities, with total capacity of about 1300 megawatts (MW) was underway and plans for a further $1000 \mathrm{MW}$ well advanced. Once these are operational, IPP generation will account for a sizeable share of output (total capacity is currently around

5. An English translation of the Electricity Sector Law can be found on website of the Ministry of National Infrastructures. 
$12000 \mathrm{MW}$ ). Reform to the rest of the supply chain is proceeding sluggishly. For instance, legislation separating network management from the IEC was drafted in 2007 by the Ministry of National Infrastructures but has yet to be approved by the Knesset.

In the absence of significant movement towards a market model, the IEC will continue to dominate the supply chain. The authorities retain powerful controls on the IECs activities. A recent consultancy report by the World Bank (2010) concludes that the operating margin of the IEC is comparable to a selection of similar operators in other countries, but it has substantial debt (and debt-servicing costs), which reduces net profitability greatly. Several factors are driving this. The IEC has little ability to influence revenues, because tariffs are set by the PUA (see Box 2), and the demand for electricity is otherwise largely governed by demographic and economic factors. In addition, all investment projects of any significance have to be approved by the Ministry of National Infrastructures. Hence, both the IEC's leeway in developing new capacity and the profile of its capital expenses are tightly controlled. Also, the strongly unionised workforce is a powerful stakeholder and has a reputation for limiting management's ability to make adjustments in labour cost and for blocking wider reform of the sector.

\section{Box 2. The main features of electricity tariff setting by the PUA}

The 1996 legislation identifies the PUA as responsible for tariff setting but gives only broad guidelines on how the tariffs should be set. The precise details are laid out in regulations that were initially developed by the PUA and finalised in consultation with the Ministry of National Infrastructures and the electricity industry. In principle, the PUA can make parametric changes to the system at will but in practice would not do so without consultation with the Ministry of National Infrastructures and the relevant operators. The current tariff system has been operating since 2002 and has the following features:

- There are several categories of consumer: "commercial and industrial"; "residential and agricultural"; "general"; and "street lighting".

- For commercial and industrial users (which account for less than $2 \%$ of customers but over $50 \%$ of electricity demand), the tariffs vary according to season and time of day (there are a total of nine categories). Rates for other users do not generally depend on time of use.

- The tariffs are calculated according to cost-based formulae that comprise three components: generation, transmission and distribution. The tariffs are set so as to yield a specified real return on equity in the three components (7\% for generation, $5.5 \%$ for transmission and $6 \%$ for distribution). The 1996 legislation provides the PUA with some discretion on which costs are included in the calculations.

- The tariffs comprise a fixed charge plus a marginal price per kWh that does not vary with volume of electricity consumed.

- The tariffs are adjusted every six months, or when costs have increased by more than $3.5 \%$ since the previous tariff adjustment (whichever comes first).

Stronger policy commitment on the direction and timeline of reform to the electricity sector is needed. As such, every effort should be made to overcome the issues that are slowing progress. The final goal of reform should be a market-based competitive model similar to those adopted in many other OECD countries. State ownership and control should be confined to the "network" segments of the supply chain, and there should be wholehearted commitment to promoting competition among the private-sector providers in both generation and distribution, where it is cost-effective and feasible to do so. Reform should entail resolution of IEC's financial difficulties, but this should be contingent on commitments by the company (and unions) to engage in the reform process. The World Bank report (commissioned by the IEC) concluded that there is a need to put the IEC on a sounder financial footing through a combination of an equity injection from the government, increases in electricity tariffs and cost-saving measures (World Bank, 2010). 
In addition, reform plans should ensure adequate generation capacity, which appears to be too low at present. More certainty on the path of development ought to also avoid the uncomfortably low reserve margin (the gap between capacity and peak demand) that has developed in recent years. According to the Ministry of National Infrastructures, the current reserve margin is around 9\% (of peak demand), which may not be adequate to guarantee reliable electricity supplies in an environment of growing demand combined with uncertainty and funding constraints that may delay investment responses. Furthermore, the Ministry expects further declines in the margin under business-as-usual assumptions. Assuming demand-management tools, such as peak-load pricing, have been fully exploited, this adds to the case for additional capacity. This problem appears to be on the way to resolution. Plans to increase reserve capacity are being implemented, which, in combination with IPPs production coming on stream, aim to push the share of reserve capacity over $15 \%$ by 2014 .

Whether electricity prices would ultimately be higher or lower as a result of such reforms is somewhat uncertain because the current price is probably artificially low. At face value, retail electricity prices (excluding tax) are relatively low in international comparison (Figure 7). However, if the World Bank's calculations are correct, then it appears the prices are not high enough to keep a monopoly provider viable (even with cost-saving measures); the IEC receives financial support from the government. Hence, reform towards a competitive structure, despite likely gains in cost effectiveness, may result in higher electricity prices. Needless to say, developments in global primary fuel prices, which are largely beyond the control of the authorities, will be an important influence on future electricity price developments, with or without reforms to the sector.

Figure 7. Household electricity prices

Prices excluding taxes, USD per kWh
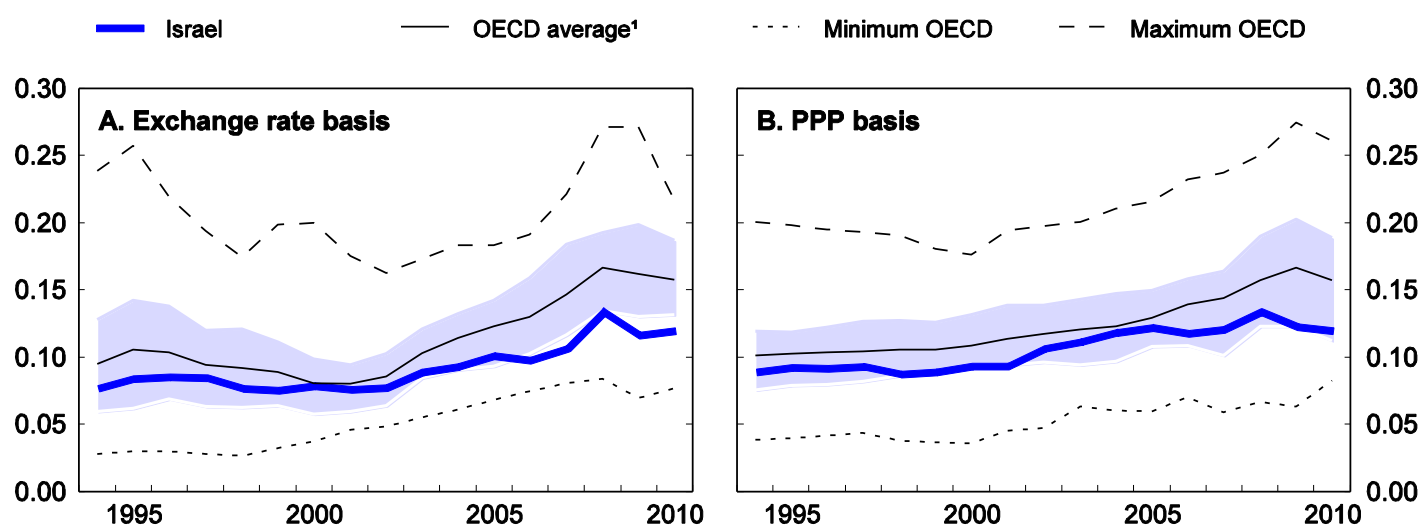

1. Unweighted average. The shaded area is the OECD range of 25 th to 75 th percentile. Half of the countries lie inside this range.

Source: OECD Economic Outlook 90 database and OECD.stat, Energy database.

\section{Environmental effects of energy use}

Many environmental externalities are closely linked to energy production and use. Most notably, emissions of greenhouse gases (GHGs) and a range of other pollutants arise from the use of hydrocarbon fuels. Israel is no exception. In 2008 (the latest available data, see OECD, 2011a) total emissions were 77.9 million tonnes of $\mathrm{CO}_{2}$ eq (including fluorinated gases, or " $\mathrm{F}$ " gases), including 40.2 tonnes (i.e. 55\% of the total) from energy industries, 15.5 tonnes (20\%) from transport, 9.7 tonnes (12\%) from manufacturing industries, industrial processing and construction, and the remainder from other sources. 
In theory, economy-wide market-based instruments can address environmental externalities in an optimal way. In particular, internalising the GHG emissions can be dealt with through participation in an international cap-and-trade scheme. However, even the most developed system, the EU's emission-trading scheme, is not yet considered effective enough to obviate the need for "flanking measures" such as carbon taxes on sectors where participation in permit trading is impracticable. Externalities in the energy sector are anyway not confined to the issue of GHG emissions. Therefore, policymakers typically use a diverse palette of regulatory and economic instruments that broadly aims to shift the energy mix away from hydrocarbons and cut back on overall energy use.

Past progress in making policy more environmentally friendly and outcomes more sustainable has been rather slow. Regulations leading to the widespread use of solar-thermal panels for water heating in the 1980s were a significant environmental achievement. As a result, water heating in over $90 \%$ of homes is at least partially provided by renewable energy. But other forms of renewable energy have not been developed to any great extent; only about $1 \%$ of electricity is currently generated from renewable sources. To be sure, the continuing substitution away from oil and coal into natural gas in electricity generation is shifting the energy mix in the right direction, but this should be at least partially interpreted as a shift in 'business as usual' (BAU) in response to purely market-based incentives, rather than purposeful environmental policy per se.

However, in recent years, environmental policy reform has gathered momentum. Some important measures have been implemented, such as the Clean Air Act (2008). This legislation effectively allows GHG emissions to be defined as a pollutant, which potentially opens the door for more stringent monitoring and regulation of GHGs for emissions from large installations. In addition, the authorities have developed a comprehensive strategy for GHG reduction and are already making headway in designing and implementing the relevant measures.

\section{Current strategy and goals in GHG-emissions reduction}

Israel has made a relatively late start in formulating explicit targets on GHG reduction and strategies for achieving them. Indeed, an explicit target for GHG-reduction was not defined until 2009. The nature of Israel's involvement in international climate-change fora may explain, in part, why targets were not adopted earlier. Israel ratified the Kyoto Protocol (which imposed quotas for GHG reduction in 2004) but was not an Annex 1 party to the United Nations Convention on Climate Change and therefore did not have to elaborate a specific emissions-reduction commitment.

A practicable 'bottom-up' process has been used to establish the target. The authorities commissioned two consultancy companies, Heifetz and McKinsey, to research possible avenues for emissions reduction. On the basis of these reports it was concluded that a reduction of $20 \%$ in GHG emissions by 2020 relative to a BAU baseline was feasible (Figure 8). This was translated into a timeline of operational goals, the focus of which is for savings of 22 million tonnes $\mathrm{CO}_{2} \mathrm{eq}$ in annual emissions by 2020. The initial assessment has been followed up by detailed plans for achieving this goal (see below).

Calculations based on the BAU of the Heifetz study imply that meeting the target will nevertheless mean a $16.5 \%$ increase in emissions by 2020 compared with those in 2005 (Figure 9). In contrast, targets in other countries typically imply reductions in aggregate emissions, some quite large. However, Israel will almost certainly continue to experience relatively rapid population and GDP growth. As a result, the implied changes in GHG emissions either per capita or per unit of GDP are much closer to those targeted elsewhere (Figure 9). 
Figure 8. Israel's GHG emissions target

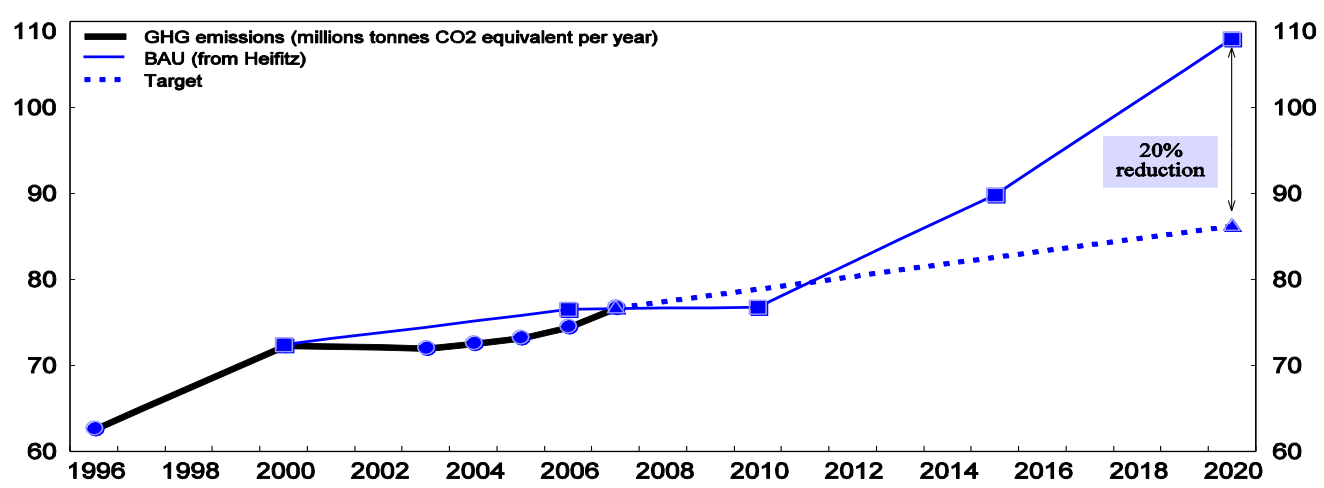

Source: Ministry of Environmental Protection.

Figure 9. International comparison of the change in emissions implied by GHG targets

Percentage change between 2005 and 2020
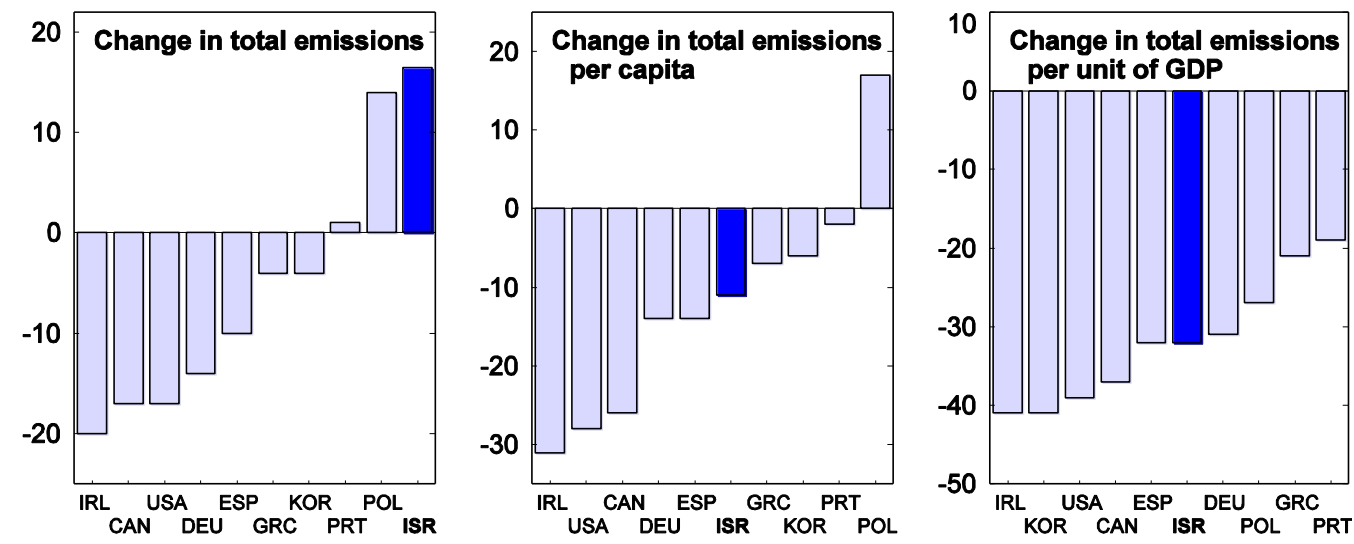

Source: OECD Medium-term baseline database; OECD Main Economic Indicators database; OECD (2011), OECD Environmental Performance Review; and OECD calculations.

The plan is for most of the emissions reduction to come from an electricity-based energy-efficiency programme and increased renewable electricity production (in total around 17 out of the $22 \mathrm{Mt} \mathrm{CO}_{2} \mathrm{eq}$ ). Savings via energy-efficiency measures aim to reduce overall electricity demand $20 \%$ below the BAU baseline by 2020 . The other goal is to increase the share of renewable electricity generation to $10 \%$, which translates into $2760 \mathrm{MW}$ of new renewable capacity. The baseline used in framing the targets estimates electricity demand of 80.5 billion $\mathrm{kWh}$ in 2020 , which implies average annual growth of $3.9 \%$, which is in the region of likely long-run growth in real GDP (Figure 10). The energy-efficiency target implies reducing average growth in electricity demand to $1.6 \%$, which requires keeping electricity consumption per capita roughly constant. Taking the renewables target into account it follows that consumption of non-renewable electricity will grow even more slowly.

The remaining $5 \mathrm{Mt} \mathrm{CO}_{2}$ eq of emissions reduction is attributed to a specific power-plant decision ("Project D", two $650 \mathrm{MW}$ plants) and an assortment of other measures. Initially, coal-fired plants were envisaged for Project $\mathrm{D}$, but it has since been decided to use combined cycle gas-fired plant with coal back-up. If the plants indeed principally use gas, then an emissions reduction of approximately $3 \mathrm{Mt} \mathrm{CO}_{2} \mathrm{eq}$ is estimated from this decision. However, at the time of writing there remained some debate on the appropriate generation strategy, with some advocating the use of coal only in extreme circumstances with 
others proposing that fuel choice should depend on economic factors (principally the relative price of coal and natural gas). Hence, it remains uncertain whether the full emissions saving will be realised.

Figure 10. Targets in energy efficiency and renewables in electricity for 2020
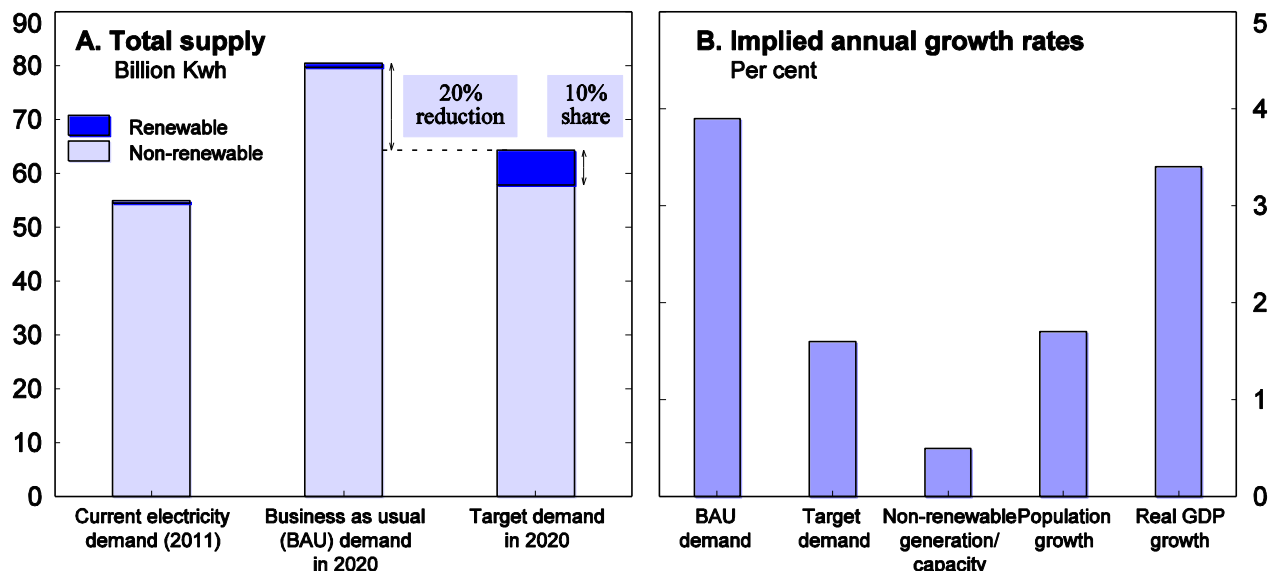

Source: Ministry of Environmental Protection; OECD Medium-term baseline database; and OECD calculations.

Targeting has so far been a one-off exercise. This should be followed up with monitoring and targeting that looks beyond 2020. This should include an independent technical assessment of progress in reaching the current target (both in relation to the percentage reduction from BAU and the level of the target). This would help keep the current target 'alive' and prevent, for instance, the goals being quietly forgotten or generously re-interpreted. Even with monitoring, the role of the current targets as an impetus to policymaking will fade as 2020 approaches. The parameters of both monitoring and further target setting ought to be clearly defined and, where possible, locked into legislation.

\section{Economy-wide instruments}

Although perhaps a distant prospect, greater participation in international emissions trading should remain a strategic goal. Currently, involvement in emissions trading is limited to the Clean Development Mechanism, which is a scheme under the Kyoto Protocol allowing Annex 1 parties to acquire emissions-reduction permits from non-Annex 1 parties (such as Israel). As of 2009, around 54 Israeli projects had been submitted for approval in the areas of waste, agriculture, fuel switching, energy and industrial efficiency (OECD, 2011a). However, the volume of emissions covered is fairly small.

One way of internalising externalities from GHG emissions is through a carbon tax. For example, a study (Palatnik and Shechter, 2010) found that such a tax would significantly reduce emissions with only a minor economic impact, even if the rate of taxation were relatively high. Furthermore, there is a relatively easy option for implementing a carbon tax in Israel. Since a large share of Israel's emissions derives from primary fuels (natural gas, coal and crude oil), then a tax on these constitutes a reasonably effective base for a carbon tax. Furthermore, excise duties on primary fuels are already imposed and could simply be adjusted to reflect a benchmark price of carbon (Table 3). In a welcome move, the excise on coal was increased to NIS 43.3 per tonne in 2011 (from NIS 8.6 per tonne), but still remains well below the values commensurate with a reasonable price of carbon. For instance, calculations suggest the excise on coal would have to be NIS 168 per tonne to be in line with a carbon price of $€ 15$ per tonne $\mathrm{CO}_{2} \mathrm{eq}$ and those on natural gas and heavy oil would have to be even higher. 
Table 3. Implied carbon prices of excises on primary fuels

\begin{tabular}{|c|c|c|c|}
\hline Fuel type & $\begin{array}{c}\text { Excise } \\
\text { (NIS/ tonne) }\end{array}$ & $\begin{array}{c}\text { Implied carbon } \\
\text { price } € / \text { tonne } \\
\mathrm{CO}_{2} \mathrm{eq}\end{array}$ & $\begin{array}{c}\text { Implied excise at } \\
€ 15 / \text { tonne } \mathrm{CO}_{2} \mathrm{eq} \\
\text { NIS/tonne }\end{array}$ \\
\hline Heavy oil & 13.9 & 0.9 & 228 \\
\hline Natural gas & 15.8 & 1.2 & 202 \\
\hline Coal & 43.3 & 3.9 & 168 \\
\hline
\end{tabular}

Note. Based on an exchange rate of $4.8 \mathrm{NIS} / €$ and that one tonne of heavy oil, natural gas and coal generate 3.17, 2.8 and 2.34 tonnes of $\mathrm{CO}_{2} \mathrm{eq}$, respectively. Natural gas is a tonne-equivalent figure.

Source: OECD calculations.

\section{Energy-efficiency schemes aim to deliver sizeable savings}

Until the adoption of the GHG-reduction target there had been no major schemes for energy saving, which implies there is ample room for efficiency gains. A comprehensive plan was approved by government in 2010 (the Greenhouse Gas Mitigation National Plan, 2011-12; see Ministry of Environmental Protection, 2011), based on a similar plan that was developed at more or less the same time (the National Energy Efficiency Program, see Ministry of National Infrastructures, 2010). The adopted plan envisages savings in electricity consumption totalling 15.95 billion kWh by 2020 through regulatory and behavioural changes. The key elements comprise: $i$ ) more stringent technical requirements on electrical appliances; ii) scrapping schemes for refrigerators and air conditioning units (these received NIS 269 million in the 2011-12 budget, and the programme proposes spending a total of NIS 1.2 billion between 2011 and 2020); iii) subsidies in industrial, commercial and public sectors (these received NIS 114 million in the budget, and total spending of NIS 626 million is proposed); iv) measures encouraging the adoption of green-building standards (which are voluntary); and, v) public information campaigns.

While the steps taken towards energy efficiency are quite comprehensive, greater attention to energy efficiency in buildings should be considered. Mandatory green standards should be introduced alongside the current voluntary system. Also, a system of mandatory energy-efficiency certification should be introduced to raise household awareness of energy costs when buying and renting property (OECD, 2011a). Also, consideration should be given to a 'virtual power station' approach similar to that proposed in the National Energy Efficiency Programme. ${ }^{6}$

\section{Policies encouraging renewable electricity generation}

Plans to reach the goal of $10 \%$ renewable-energy generation comprise a mix of tenders for production and quota-based feed-in tariffs. Thermo-solar and large-scale photovoltaic (PV) facilities along with wind generation are slated to account for the lion's share of the future increase in capacity (Table 4). The allocation of tenders and setting of feed-in tariffs has progressed reasonably (Table 5), and the authorities should work to overcome any obstacles to further development as they arise. As of October 2011, a large

6. The National Energy Efficiency Program was very similar to the plan adopted by the government, but notably it also proposed establishing a special fund to finance the programme using revenues from a special tax incorporated into consumer tariffs for electricity. Technically, the tax would comprise a $1 \%$ levy on suppliers' revenues from electricity sales. However, the tax would be a 'recognised expense' for the purposes of tariff setting, which means it would be fully passed on in higher prices to the consumer. The special fund made economic sense, in that the proposed tax was reckoned roughly equal to the tariff increase that would be required to fund additional electricity generation if the energy savings were not made. So, in effect, the tax combined with the energy-efficiency measures would represent a (government-run) 'virtual' power station whose 'generation' comprises energy savings. 
share of the intended tenders and quotas for feed-in tariffs for solar-electricity generation had been allocated. However, no contracts had been signed for wind generation, and little progress had been made in lining up biogas or biomass production. Also, there remain further regulatory hurdles before construction can begin. In particular, if installation requires a "change of land use" according to planning law, then this can significantly slow down or even halt development entirely. This will apply to the larger installations planned, but not necessarily to smaller units. According to the Ministry of Environmental Protection, steps have been taken to clarify and, where possible, ease the land-use rules (OECD, 2011a). ${ }^{7}$

Table 4. Progress in plans to increase solar- and wind-powered electricity generation

\begin{tabular}{|c|c|c|c|}
\hline & Planned mechanisms & State of play as of November 2011 & $\begin{array}{c}\text { Intended } \\
\text { capacity by } 2020 \\
(\mathrm{MW})\end{array}$ \\
\hline \multirow{3}{*}{$\begin{array}{l}\text { Large } \\
\text { thermo-solar or } \\
\text { PV }\end{array}$} & $\begin{array}{l}\text { Mixture of tenders and quota-limited } \\
\text { feed-in tariffs. }\end{array}$ & $\begin{array}{l}460 \mathrm{MW} \text { of licensed tariff production has been made } \\
\text { available. }\end{array}$ & 1200 \\
\hline & & $\begin{array}{l}\text { In addition, tenders for three plants located in } \\
\text { Ashelim (totalling } 250 \mathrm{MW} \text { ) have been allocated. A } \\
\text { price equivalent to about US } 30 \text { cents per kWh has } \\
\text { been guaranteed for the initial years of production. }\end{array}$ & \\
\hline & & $\begin{array}{l}\text { A tender for a thermal solar plant ( } 280 \mathrm{MW}) \text { has } \\
\text { been issued but has not yet been awarded. }\end{array}$ & \\
\hline Medium PV & Feed-in tariff, quota based & $\begin{array}{l}\text { About } 5 \mathrm{MW} \text { production installed and construction } \\
\text { due to begin on units totalling } 70 \mathrm{MW} \text { capacity. A } \\
\text { total of } 300 \mathrm{MW} \text { quota has been made available and } \\
\text { is reportedly over-subscribed. The guaranteed price } \\
\text { is equivalent to about US } 40 \text { cents per kWh. }\end{array}$ & 350 \\
\hline $\begin{array}{l}\text { Rooftop PV up } \\
\text { to } 50 \mathrm{KW}\end{array}$ & $\begin{array}{l}\text { Feed-in tariff. Quota-limited unless } \\
\text { located in the periphery or up to } \\
4 \mathrm{KW} \text { capacity (in which case no } \\
\text { quota). }\end{array}$ & $\begin{array}{l}\text { A first quota ( } 80 \mathrm{MW} \text { ) has been fully subscribed and } \\
\text { an additional quota of } 120 \mathrm{MW} \text { has been made } \\
\text { available. The guaranteed price is equivalent to } \\
\text { about US } 50 \text { cents per kWh. }\end{array}$ & 200 \\
\hline Wind & $\begin{array}{l}\text { Mixture of tenders and quota-limited } \\
\text { feed-in tariffs }\end{array}$ & $\begin{array}{l}\text { Current installed capacity is small. No tenders for } \\
\text { new capacity have been allocated as yet. }\end{array}$ & 800 \\
\hline Biogas, biomass & Feed-in tariff, quota based & $\begin{array}{l}\text { No installed capacity. In } 2010 \text { a private-sector } \\
\text { proposal for a plant was derailed by local opposition. }\end{array}$ & 210 \\
\hline Total & & & 2760 \\
\hline
\end{tabular}

Source: OECD (2011a).

Israel's approach to renewables seems reasonable, given the aim of ensuring a certain level of renewables generation capacity. One implication is that the implicit subsidies provided by the guaranteed prices are probably well above the benchmark price of carbon and other externalities. Based on the range of feed-in tariffs in Table 5, rough calculations imply an implicit price of abatement from about $€ 250$ to 400 per tonne of $\mathrm{CO}_{2}$ eq. ${ }^{8}$ However, implicit abatement costs of this order of magnitude are found in many OECD countries. Even in the absence of such targets, some would argue that renewables require 'additional' subsidisation to spur on technological development.

7. For instance, rooftop PV requires only a building permit (not a planning permit); generation under 50 MW requires approval only by regional planning authorities (not national planning too) and, all installation of PV units in open space, agricultural land or elsewhere is regarded as a change of use.

8. Based on assuming electricity generated from hydrocarbon fuels produces 0.7 tonnes $\mathrm{CO}_{2}$ eq per megawatt hour, and costs USD 0.04 per kilowatt hour. Exchange rates are assumed to be NIS 3.6 per USD and $€ 0.7$ per USD. For a recent international comparison of implied abatement costs of feed-in tariffs see OECD (2011b). 
Table 5. Key incentive mechanisms for renewable energy

\begin{tabular}{|c|c|}
\hline \multirow[t]{2}{*}{ Feed-in tariffs } & $\begin{array}{l}\text { Feed-in tariffs (NIS per KWH) for the current quotas are } 1.51 \text { for facilities up to } 50 \mathrm{KW}, 1.1 \text { up to } 60 \mathrm{MW} \\
\text { and } 1.02 \text { for above } 60 \mathrm{MW} \text { capacity. The feed-in rates will begin to fall in } 2014 \text {, with complete phase-out } \\
\text { by } 2020 \text {. }\end{array}$ \\
\hline & Quotas are allocated on a first-come, first-served basis. \\
\hline Tenders & $\begin{array}{l}\text { Tenders will generally be of a build-operate-transfer (BOT) format. In some the bids will be based on the } \\
\text { price of electricity delivered and for others on the land rental for the facility. }\end{array}$ \\
\hline Tax breaks & $\begin{array}{l}\text { A } 25 \% \text { annual depreciation allowance on solar power electricity facilities was introduced in May } 2010 \text {. } \\
\text { Under consideration. Further tax advantages for facilities that have a "local value added" exceeding } 70 \% \text {. } \\
\text { Subject to approval. Tax-free allowance (up to NIS } 18000 \text { per year) on household income from rooftop PV or } \\
\text { wind installations. }\end{array}$ \\
\hline Other issues & $\begin{array}{l}\text { Profit-sharing conditions. In cases where a facility takes up agricultural land (including pasture for animals) } \\
\text { and where local communities have some legal claim to the land (even where, strictly speaking it is state } \\
\text { owned), then the provider must split the profits on a 50-50 basis with the local community. }\end{array}$ \\
\hline
\end{tabular}

Source: OECD (2011a).

Even if the target for renewables were fulfilled, $90 \%$ of electricity generation would be hydrocarbon-based (albeit comprising a large proportion of natural gas) and therefore be producing GHGs. There are no practicable ways of improving this figure by other means in the short run. Carbon capture and storage (CCS) technologies provide one potential solution, but they are not yet sufficiently developed for widespread commercial use. In principle, nuclear power could also substantially reduce GHG-emissions relating to electricity generation. However, continuing uncertainty regarding nuclear power's advisability, particularly in relation to safety risks, and political factors suggest that it is not a feasible option, certainly in the near term.

\section{Energy use in transport}

Israel's relatively rapid growth in population and economic activity has been echoed in transport activity, bringing increased environmental pressures and placing heavy demands on transport infrastructure. Total road transport has increased steadily, with 50 billion kilometres travelled by all types of motor vehicle in 2009 compared with 19 billion in 1990 (Figure 11, Panel A), and private cars continue to account for the majority of kilometres travelled. Indeed, distances travelled by buses have decreased in relation to private cars (Panel B). However, rail travel has increased quite rapidly, though from a very low base. As of 2009, there were nevertheless only 6.3 passenger kilometres of train travel per $100 \mathrm{~km}$ driven by private cars (N.B. not passenger kilometres). Given the heavy focus on road transport to date, policy should pursue a two-pronged strategy that ensures the cost of private-vehicle use (including road freight) fully reflects externalities while simultaneously widening the options for other forms of transport.

\section{Vehicle taxation and road charging}

Vehicle taxation has historically been viewed largely as a useful source of public revenue with only a loose connection with environmental concerns. Yet, the environmental credentials of traditional vehicle taxes are coming under increasing scrutiny, and taxes and charges specifically designed to deal with environmental externalities in transport are being introduced as part of a "green-growth" strategy."

9. For an overview of taxation and the environment see OECD (2010) and for a recent summary of green-growth issues, see de Serres et al. (2010). 
Figure 11. Indicators of transport activity
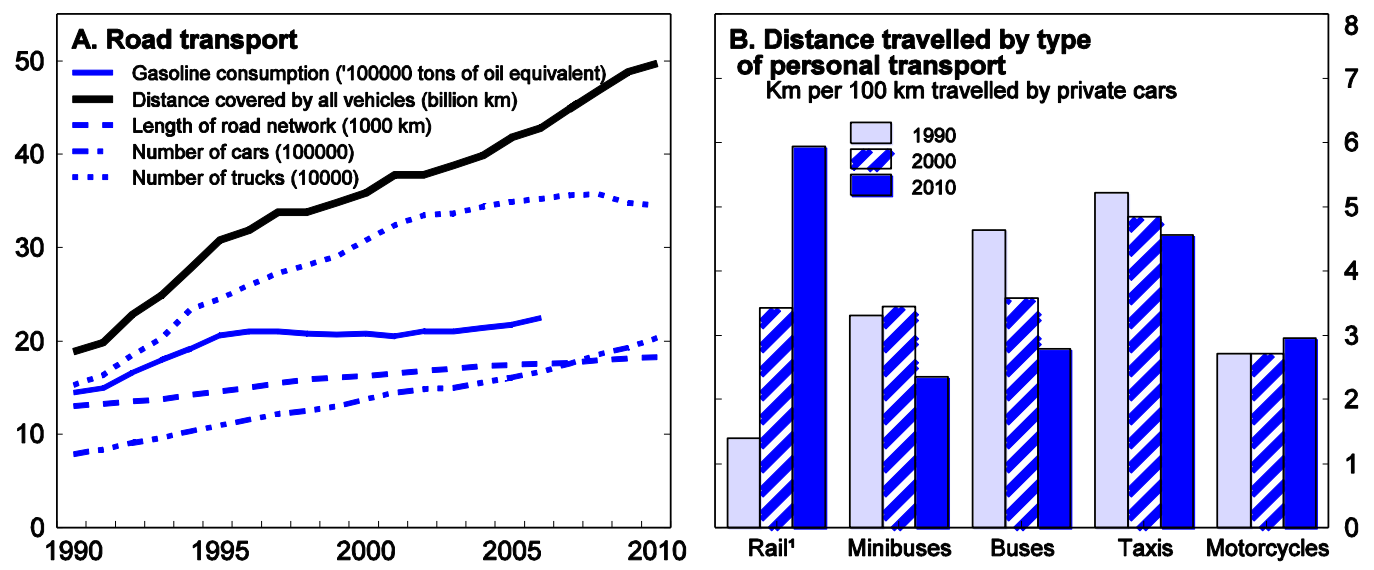

1. For rail the data indicate refer to the number of passenger kilometres, the remaining data indicate the number of kilometres travelled by each vehicle type.

Source: Central Bureau of Statistics.

A recent scheme differentiating purchase taxes on cars according to environmental criteria is admirable in many respects, but as the 2010 OECD Economic Survey argued, the range of rates ought to be shifted down. For decades, very high taxes have been imposed on the purchase of private vehicles. In 2009, a new system was introduced that maintains a high basic purchase tax (currently 83\%), but allows for downward adjustment through a 'green credit' based on emissions (see Box 3). A range of exhaust pollutants is incorporated in the credit, as well as $\mathrm{CO}_{2}$, which is particularly commendable. The introduction of the credits is reckoned to have shifted purchases from high to low polluting vehicles by $5 \%$ (Bank of Israel, 2011, p. 262). However, the overall scale of these taxes remains at a level that is hard to justify on economic grounds. ${ }^{10}$ They substantially distort relative prices and on environmental grounds it makes more sense to target car use. The authorities have already lowered the basic rate of purchase tax once (from 90\%) since introducing the new system. Also, in broader terms the share of vehicle-related revenues relating to car use has been increasing, for instance it increased from 43 to $56 \%$ between 2001 and 2009. Further reductions in the basic rate of purchase tax should be made, in combination with measures to increase the cost of vehicle use, e.g. via road pricing, congestion charges, and/or higher excise tax on fuel, possibly in the form of a carbon tax.

Taxes and charges on car use are more closely aligned to emissions-related externalities than those on car purchase (or similar mechanisms). Indeed, evidence from a Bank of Israel study shows the reduction in vehicle mileage from an increase in the price of gasoline is three times bigger than that from a similar revenue increase through purchase taxes. ${ }^{11}$ However, there are a number of policy issues:

10. Environmental taxes on car purchases can be superior to those on car use for those pollutants where the emissions vary significantly depending on the technical characteristics of the vehicle (e.g. for $\mathrm{NO}_{\mathrm{x}}, \mathrm{PM}$ and hydrocarbons). In such circumstances, the same car use (in terms of fuel consumption or similar metrics) can have very different emissions levels. As such, a purchase tax can be preferable, even though this on its own implies no marginal charge for the additional emission.

11. Bank of Israel (2010) shows that a $1 \%$ increase in the purchase price of cars is estimated to cut total mileage by about $0.06 \%$ and raise about NIS 166 million, while a $1 \%$ increase in gasoline price is estimated to reduce mileage by about $0.18 \%$ and raise about NIS 178 million. By implication, even a revenue-neutral shift from purchase tax to gasoline tax would be helpful. If the purchase price is reduced by $1 \%$ and the price of gasoline increased by $1 \%$, mileage would be lowered by $0.12 \%$. 


\section{Box 3. Details of car purchase tax}

Aside from some temporary exceptions (see below) the car purchase tax is calculated as follows:

Purchase tax = basic rate (\% of price of car excluding value-added tax) less a "green credit" (a value in NIS).

The basic rate is currently $83 \%$, lowered from $90 \%$ when the green credit was first introduced in 2009 .

The green credit is based upon an index reflecting the emissions characteristics of the vehicle weighted by values reflecting externality costs (expressed in euros per tonne). The index covers emissions of carbon dioxide $\left(\mathrm{CO}_{2}\right)$, carbon monoxide $(\mathrm{CO})$, hydrocarbons $(\mathrm{HC})$, nitrogen oxide $(\mathrm{NOx})$ and particulates $(\mathrm{PM})$ with cost weights of 30,500 , 900,10000 and 20000 , respectively. For instance, a car with emissions of 162, 0.75, 0.05, 0.03 and 0 grammes per $\mathrm{km}$ for $\mathrm{CO}^{2}, \mathrm{CO}, \mathrm{HC}, \mathrm{NO}_{\mathrm{x}}$ and $\mathrm{PM}$ generates an interim value of 5580 , this is then divided by 30 to arrive at a green credit value of 186. Each index value is then associated with a particular green credit according to 15 emission groups. An index of 251 or above (emission group 15) receives no credit, while the maximum credit for a regular car is emission group 3 where the credit was worth NIS 15261 as of 2011.

Example. In theory, the possible range of purchase tax for a regular car with a pre-tax showroom price of NIS 50000 (USD 13800 at an exchange rate of 3.6) is NIS 26239 to NIS 41500 , i.e. 52 to $83 \%$. Adding in VAT (at 16\%) increases the range to 68 to $99 \%$. The total retail price of the car can therefore range between NIS 84239 and NIS 99 500, depending on its emissions characteristics.

Purchase taxes on electric and hybrid vehicles are treated differently. The purchase tax on electric cars is currently $10 \%$. It will rise to $30 \%$ in 2015 and from 2020 it will be calculated as per the formula above (with a corresponding green credit). Similarly, for hybrid vehicles the purchase tax rate is currently $30 \%$ and will rise to $45 \%$ in 2015 and from 2020 as per the method above. The implicit subsidy to electric vehicles is quite substantial. For example, the purchase tax on an electric car costing NIS 50000 is NIS 5000 , implying a 'subsidy' over a regular car ranging from NIS 21239 to NIS 36500 (equivalent to USD 5900 to USD 10 138).

- Israel is unusual in that retail gasoline prices are regulated by a formula that, inter alia, is based on the market price of crude oil. This regulation essentially aims to counter the risk of weak competition because two providers dominate the supply chain for vehicle fuels. Comparison of the net price of gasoline (i.e. excluding VAT and excise duty) in dollar terms indicates the regulation results in a price similar to many OECD countries', and, on this basis, the formula appears to mimic market-based pricing reasonably well. Nevertheless, it would be preferable if the price regulation were made redundant through stronger competition in the supply chain.

- There is some headroom to increase the taxes on gasoline and diesel. Figure 12 implies that households and businesses in some other OECD countries tolerate higher levels than Israel's and on this (simple) basis there is some room for hikes in excise duty while remaining within the boundaries of international experience. Furthermore, precise environmental justification for further hikes in gasoline tax is possible, although it would have to be somewhat sophisticated. As for other countries with 'European' sized excise duties, precise environmental justification either has to assume a very high implied price of $\mathrm{CO}_{2} \mathrm{eq}$, or take on board additional externalities (see Persson and Song, 2010). This is illustrated in Figure 13, which compares the tax on gasoline and diesel in Israel and selected other economies against indicative values of various externalities. While there may be headroom on economic grounds for raising excise on gasoline and diesel, in 2011 at least, the political climate has not been conducive. A hike in excise on gasoline and diesel was postponed in January due to adverse public reaction (unfortunately for the authorities, the world price of oil had risen significantly at the time) and the package of tax measures approved by the government in October 2011 included cancellation of an excise tax increase scheduled for January 2012 (see Assessment and recommendations). 
Figure 12. Prices and taxes on gasoline and diesel

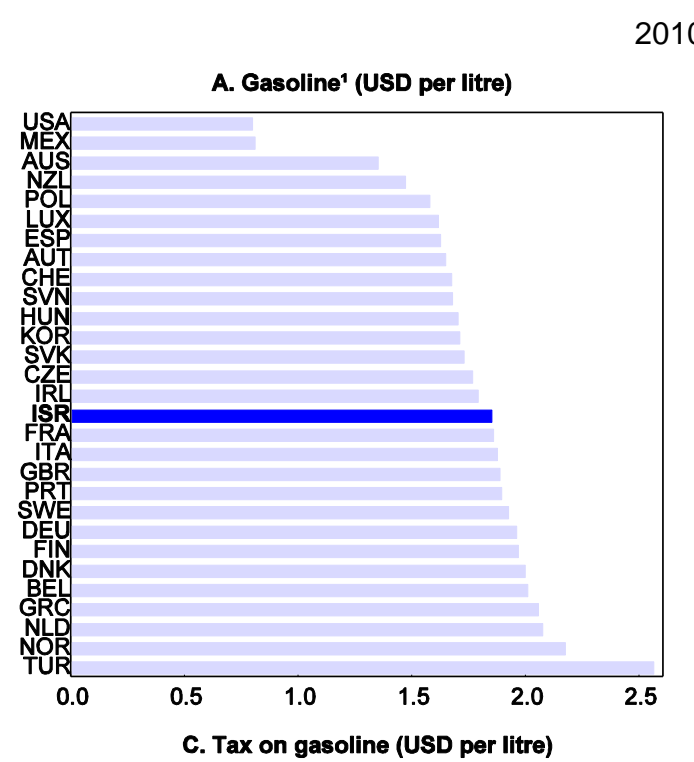

2010 q4
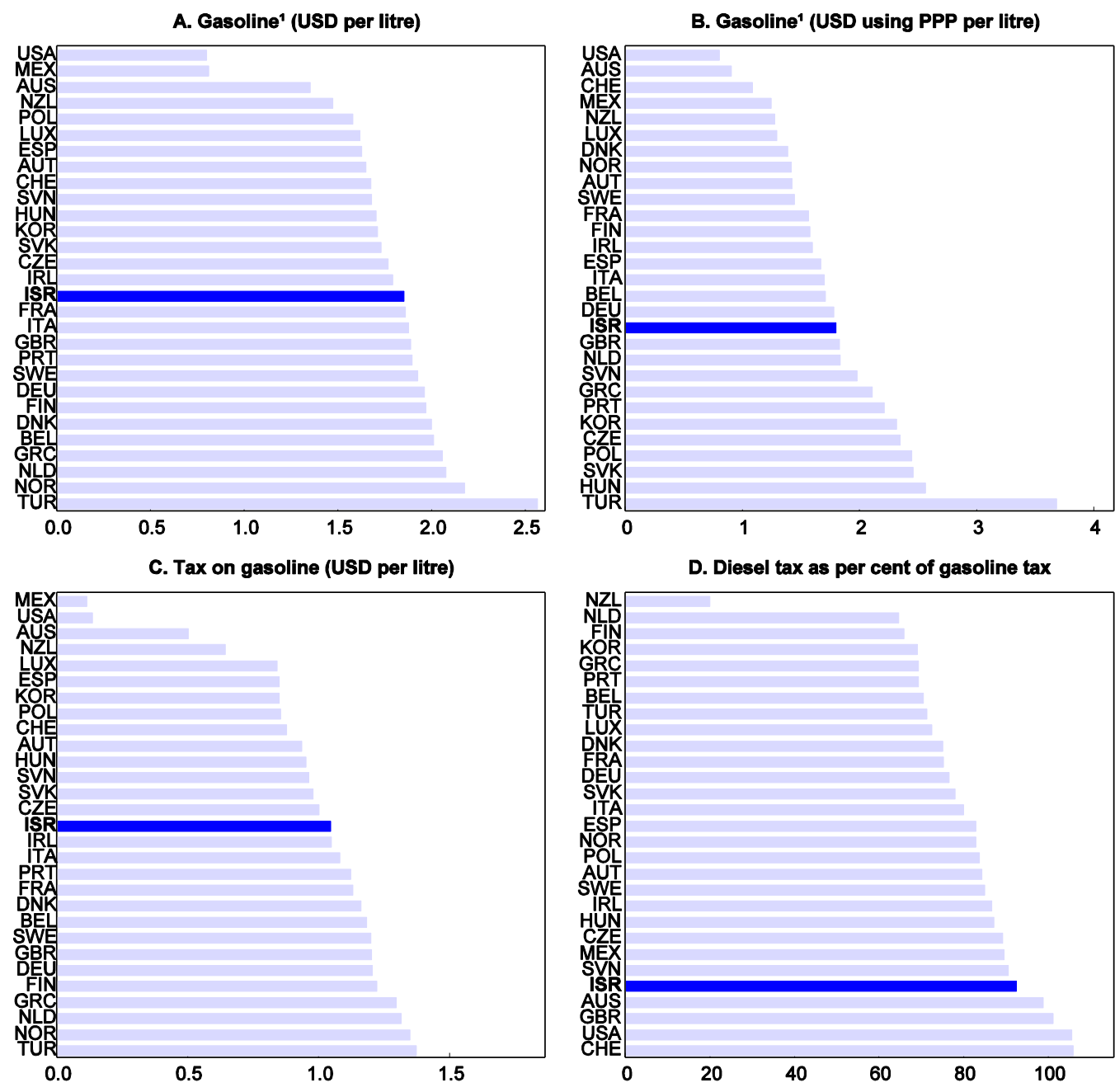

1. Unleaded premium $95 \mathrm{RON}$; Taxes comprise both excises and VAT.

Source: OECD, OECD.stat - Energy database and OECD Economic Outlook 90 database.

- Road pricing and other schemes targeting car use should be explored further. Most road pricing to date has arisen on a somewhat limited and piecemeal basis from build-operate-transfer (BOT) deals between government and the private sector for the development of certain sections of road. However, an innovative scheme on the main highway into Tel Aviv from the south east began operating at the beginning of 2011. One lane is reserved for paying customers and free for public transport (plus those with three or more passengers). Toll station queues are avoided through camera recognition of the vehicle in conjunction with a web-based payment system. Perhaps even more interesting is that the price varies on a real-time basis according to traffic conditions. 
Figure 13. Taxes on gasoline and diesel compared with estimates of externalities
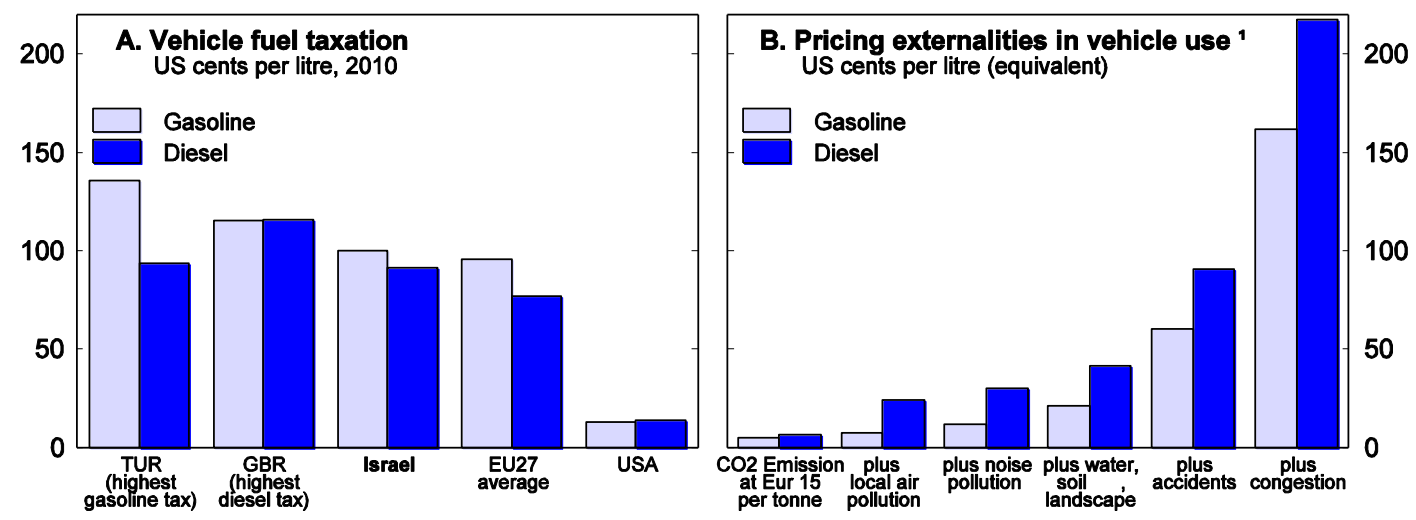

1. Key assumptions: fuel consumption of 7.5 litres and 6 litres per $100 \mathrm{~km}$ for gasoline and diesel, respectively; emission of 2.35 and $3.23 \mathrm{Kg} \mathrm{Co} 2$ per litre of gasoline and diesel, respectively. CE Delft externalities in EUR cents per km (at prices in year 2000): Local air pollution (EUR 4 fuel standard), petrol: 0.1; Local air pollution (EUR 4 fuel standard), diesel: 0.6; noise: 0.2; Nature, landscape, soil water pollution: 0.4; Accidents: 1.7; Congestion: 4.4.

Source: IEA, Energy prices database; OECD calculations based on CE Delft Handbook results reported in Persson and Song (2010).

The tax treatment of company cars (these are typically provided via leasing companies) should be further adjusted so that employees face marginal social costs for car use. In all countries, the tax treatment of company cars is tricky, because it is difficult for the authorities to elicit reliable information on the division between private and professional use. Historically, Israel's approach has been generous. For companies, all expenses (leasing, maintenance and fuel) are fully tax deductable, with no cap. Not surprisingly, the provision of company cars has been widespread. According to a report by the State Revenue Authority there were 304000 company cars in 2008, or about $16 \%$ of the 1.9 million private vehicles. The Bank of Israel has calculated that around $10 \%$ of employees had a company car in that year. Since 2008, there has been some improvement in policy, with inclusion of an estimated value of company cars in the personal income tax bases of employees. These vary according to the car's characteristics (including emissions characteristics) and have been gradually increased between 2008 and 2011. This move will have at least reduced the incentives for providing company cars, especially ones with high emissions. However, the problem still remains that once an employee gets a company car, the marginal costs of car use are practically zero, because the employers still cover the full (private) costs. Further reform is needed. For instance, a cap on the tax offset on the fuel expenses for the company could be introduced, similar to that already in place for company phones. Preferably the cap should be expressed in terms of fuel use, rather than distance travelled. A fuel-use cap can be easily checked by the tax authorities and gives better incentives for companies to buy fuel-efficient cars and for fuel-conscious driving by employees. In addition, the "car allowances" that feature in the public sector and banking should at least be reduced significantly. Also, provision of free parking to employees should be reviewed.

Electric car usage (practically zero at present) is being encouraged through implicit subsidies in the system of purchase tax (see Box 3 and OECD, 2011c). In addition a private-sector system (run by the company Better Place) is due to come on stream that involves battery changing and charging stations (users will not own the batteries but instead pay for a battery service), and the authorities have been setting the ground rules for the technical specification, location and market access of the stations. The environmental implications of electric vehicles depend crucially on what can be reasonably assumed about the emissions of the additional electricity generated to charge the vehicle. In Israel's case, if the marginal emissions in electricity production resemble average emissions, then the environmental impact is quite small because generation continues to rely quite heavily on coal and oil. Alternatively, if it can be assumed 
that additional production will be gas-based (which is not unreasonable in the Israeli context), then the environmental benefits of shifting to electric cars are substantially improved. ${ }^{12}$

Additional regulation and public-information campaigns in private transport should also be considered, as long as these do not generate excessive economic distortion and inefficiencies and are practicable in terms of implementation and monitoring. The International Energy Agency, for example, recommends regulations relating to tyre standards and use, mandatory efficiency standards for goods vehicles and the promotion of fuel-efficient driving (International Energy Agency, 2008).

\section{Alternatives to private car transport need improving}

Tax incentives to discourage the use of private vehicles are unlikely to have a large impact on behaviour without more comprehensive and co-ordinated public transport and the exploitation of feasible alternatives to road-freight transport. To date, public transport has largely comprised state-subsidised bus services, with one company (Dan) being the main provider in Tel Aviv and its environs and another (Egged) running services in most of the other main urban areas. Smaller communities and inter-urban services are run by Egged and several other companies.

Concrete progress in expanding the currently limited rail network has been slow, but recent commitments are encouraging. Following multiple delays due to technical and funding difficulties, a light rail line in Jerusalem began operating in August 2011. However, construction of a long-planned light rail line in Tel Aviv has only just begun. The prospects for inter-city rail links look reasonable with the establishment of a development plan in 2010 that notably aims to complete the construction of a rapid rail link between Tel Aviv and Jerusalem by 2017. In addition, a more general plan for transport was also agreed in 2010 that includes plans for further new rail links and electrification. Unfortunately, it is uncertain whether these plans will go ahead as envisaged, given the past record of delay in developing the rail network.

In a welcome move, metropolitan transport authorities are planned, most notably, one for the Tel Aviv and the surrounding area. Currently, urban transport suffers from poor co-ordination between transport modes, an issue that a regional transport authority would be well placed to address.

12. Average emissions in Israeli electricity production are around 700 grams per $\mathrm{kWh}$ while purely gas-fired generation may only generate around 185 grammes of $\mathrm{CO}_{2}$ eq per $\mathrm{kWh}$. Assuming an electric car requires $0.13 \mathrm{kWh}$ per $\mathrm{km}$ therefore implies emissions of 90 or 24 grammes $\mathrm{CO}_{2} \mathrm{eq}$ of per kilometre for average emissions and gas-fired emissions, respectively. OECD (2011d) provides a more detailed comparison of electric and conventional vehicles marketed in France, which are the similar to those that will be marketed in Israel. 


\section{Box 4. Recommendations for energy policies}

\section{Gas sector}

- Channel the proceeds from natural gas into an independently managed sovereign wealth fund. The fund should be established sooner rather than later.

- Do not subsidise downstream investment to facilitate export or increased demand for natural gas.

\section{Electricity sector}

- Make stronger policy commitment on the direction and timeline of reform to the electricity sector. The final goal of reform should be a market-based competitive model.

- Resolve IEC's financial difficulties contingent on commitments by the company (and its unions) to engage in the reform process. Ensure adequate generation capacity.

\section{Energy and the environment}

- Follow up the one-off GHG-targeting exercise with monitoring and a system of rolling targets that looks beyond 2020.

- Consider an economy-wide carbon tax by modifying the existing excise tax on primary fuels and aim for greater participation in international emissions trading.

- $\quad$ Expand plans for energy efficiency in buildings. Introduce mandatory green standards alongside the current voluntary system. Also, introduce mandatory energy-efficiency certification.

- Overcome impediments to getting renewable energy on stream, in particular land-use planning and permit processing.

\section{Energy and the transport sector}

- $\quad$ Pursue a two-pronged strategy that ensures the cost of private-vehicle use, including road freight, fully reflects externalities while simultaneously widening the options for alternative forms of transport.

- Fully implement the plans to extend rail services.

- Improve taxes and charges relating to vehicle use:

- Maintain the green credit system, but reduce the basic rate of purchase tax (currently $83 \%$ ).

- Make greater use of taxes and charges on car use.

- Adjust the tax treatment of company cars such that employees face positive marginal costs when driving them for private use. Replace the employee car allowances that are provided in some private service sectors and the public sector with other forms of compensation.

- Consider additional regulation and public-information campaigns to promote efficiency savings in vehicle use. 


\section{Bibliography}

Bank of Israel (2010), Annual Report 2009, Jerusalem.

Bank of Israel (2011), Annual Report 2010, Jerusalem.

De Serres, A., F. Murtin and G. Nicoletti (2010), "A Framework for Assessing Green Growth Policies", OECD Economics Department Working Papers, No. 774, Paris.

International Energy Agency (2008), Energy Efficiency Policy, Recommendations, International Energy Agency, Paris.

International Energy Agency (2010a), Technology Roadmap, Solar Photovoltaic Energy, International Energy Agency, Paris.

International Energy Agency (2010b), Technology Roadmap, Concentrating Solar Power, International Energy Agency, Paris.

Ministry of Environmental Protection (2011), “Greenhouse Gas Reduction Action Plan”, Environmental Bulletin, No. 37, September.

Ministry of National Infrastructures (2010), National Energy Efficiency Plan, Jerusalem.

OECD (2010), Taxation, Innovation and the Environment, OECD Publishing, Paris.

OECD (2011a), Environmental Performance Review of Israel, OECD Publishing, Paris.

OECD (2011b), OECD Economic Surveys: France, Vol. 2011/2, OECD Publishing, Paris.

OECD (2011c), Better policies to support eco-innovation, OECD Publishing, Paris.

OECD (2011d), Prospects for electric vehicles-an illustration with models marketed in France, OECD Publishing, Paris, forthcoming.

Palatnik, R.R. and M. Shechter (2010), "The Israeli Economy and Potential Post-Kyoto Targets", Israel Economic Review, Vol. 8, No. 1.

Persson, J. and D. Song (2010), “The Land Transport Sector”, OECD Economics Department Working Papers, No. 817, Paris.

Schenk, C.J., M.A. Kirschbaum, R.R. Charpentier, T.R. Klett, M.E. Brownfield, J.K. Pitman, T.A. Cook and M.E. Tennyson (2010), Assessment of undiscovered oil and gas resources of the Levant Basin Province, Eastern Mediterranean, U.S. Geological Survey Fact Sheet 2010-3014, Washington, D.C.

Shaffer, B. (2011), "Israel-New natural gas producer in the Mediterranean”, Energy Policy 39, Elsevier.

State of Israel (2011), Conclusions of the committee for the examination of fiscal policy with respect to oil and gas resources in Israel, January.

World Bank (2010), Study of Israel Electric Corporation's Tariffs and Financial Situation, World Bank report submitted to the Israel Electric Corporation, Washington, D.C. 
ECO/WKP(2011)83

\section{WORKING PAPERS}

The full series of Economics Department Working Papers can be consulted at www.oecd.org/eco/workingpapers/

913. Issues in private-sector finance in Israel

(December 2011) by Philip Hemmings

912. How to improve the economic policy framework for the housing market in Israel

(December 2011) by Philip Hemmings

911. Fiscal prospects and reforms in India

(December 2011) by Richard Herd, Sam Hill and Vincent Koen

910. Structural reforms to reduce unemployment and restore competitiveness in Ireland

(December 2011) by Álvaro Pina

909. Getting back on track: restoring fiscal sustainability in Ireland

(December 2011) by David Haugh

908. A welfare analysis of climate change mitigation policies

(November 2011) by Alain de Serres and Fabrice Murtin

907. Overcoming the banking crisis in Ireland

(November 2011) by Muge Adalet McGowan

906. Macroeconomic and structural policies to further stabilise the Mexican economy

(November 2011) by Cyrille Schwellnus

905. Reaping the benefits of a transition to greener growth in Slovakia

(November 2011) by Caroline Klein

904 Fiscal reform for a stronger fairer and cleaner Mexican economy

(October 2011) by Nicola Brandt and Rodrigo Paillacar

903 The demand for safe assets in emerging economies and global unbalances: new empirical evidence (October 2011) by Rudiger Ahrend and Cyrille Schwellnus

902. Drivers of systemic banking crises: the role of bank-balance-sheet contagion and financial account structure

(October 2011) by Rudiger Ahrend and Antoine Goujard

901 Explaining the appreciation of the Brazilian Real

(October 2011) by Annabelle Mourougane

$900 \quad$ Raising investment in Brazil

(October 2011) by Jens Arnold

899 Refining macroeconomic policies to sustain growth in Brazil

(October 2011) by Annabelle Mourougane 
898. Promoting infrastructure development in Brazil

(October 2011) by Annabelle Mourougane and Mauro Pisu

897. Austria: public sector inefficiencies have become less affordable (October 2011) by Karin Fischer, Rauf Gönenç and Robert Price

896. Informality in Mexico

(September 2011) by Nicola Brandt

895. Reforming Austria's highly regarded but costly health system

(September 2011) by Rauf Gönenç, Maria. M. Hofmarcher, Andreas Wörgötter

894 Greener growth in the Belgian federation

(September 2011) by Tomasz Koźluk

893. Green growth and climate change policies in New Zealand

(September 2011) by Alexandra Bibbee

892. Has deregulation increased investment in infrastructure? Firm-level evidence from OECD countries

(September 2011) by Sónia Araújo

891. Ensuring a Sustainable and Efficient Fishery in Iceland

(September 2011) by Gunnar Haraldsson and David Carey

890. Japan's New Growth Strategy to create demand and Jobs

(September 2011) by Randall S. Jones and Byungseo Yoo

889. Labour market reforms in Japan to improve growth and equity

(September 2011) by Randall S. Jones and Satoshi Urasawa

888. Education reform in Japan

(September 2011) by Randall S. Jones

887. The Political Economy of Climate Change Mitigation Policies: How to Build a Constituency to Address Global Warming?

(August 2011) by Alain de Serres, John Llewellyn and Preston Llewellyn

886. Climate-Change Policy in the United Kingdom

(August 2011) by Alex Bowen and James Rydge

885. Improving Access and Quality in the Indian Education System

(August 2011) by Sam Hill and Thomas Chalaux

884. How Institutions Shape the Distributive Impact of Macroeconomic Shocks: A DSGE Analysis (July 2011) by Rudiger Ahrend, Charlotte Moeser and Tommaso Monacelli

883. Can India Achieve Double-Digit Growth?

(July 2011) by Richard Herd, Paul Conway, Sam Hill, Vincent Koen and Thomas Chalaux 